\title{
Competitor Standing to Challenge a Merger of Rivals: The Applicability of Strategic Behavior Analysis
}

\begin{abstract}
Recent changes in governmental antitrust enforcement policy have forced private parties, particularly competitors, to file private suits to enjoin mergers. Some commentators have argued that a competitor cannot establish standing to challenge a merger of rivals, because it cannot demonstrate an "antitrust injury" as required by the Clayton Act and Cargill, Inc. v. Monfort of Colorado, Inc. This Comment argues that a competitor can demonstrate antitrust injury by means of strategic behavior analysis-a new method of understanding market structure and competition. Drawing on the Clayton Act's legislative history and case law, it first develops a proposed standard of antitrust injury. It then describes strategic behavior analysis and argues that such analysis can identify those mergers that threaten antitrust injury to competitors by positioning the merged firm to engage in anticompetitive strategic behavior. It concludes by considering some hypothetical mergers to illustrate the sorts of cases in which a private plaintiff can use strategic behavior analysis to meet the proposed standard for antitrust injury.
\end{abstract}

\section{INTRODUCTION}

Until recently, government intervention was the primary means of preventing anticompetitive mergers. ${ }^{1}$ Few private plaintiffs sought to enjoin illegal mergers through the standing granted them by section 16 of the Clayton Act. ${ }^{2}$ But in 1982, the Department of Justice issued new guidelines ${ }^{3}$ by which it would determine whether a proposed inerger would produce the anticoinpetitive effects prohibited by section 7 of the

1. The broad scope of the Clayton Act condemns mergers when "the effect of such acquisition may be substantially to lessen competition." 15 U.S.C. $§ 18$ (1982 \& Supp. 1985).

2. Section 16 states:

Any person, firm, corporation, or association shall be entitled to sue for and have injunctive relief, in any court of the United States having jurisdiction over the parties, against threatened loss or damage by a violation of the antitrust laws, including sections 13, 14,18 , and 19 of this title, when and under the same conditions and principles as injunctive relief against threatened conduct that will cause loss or damage is granted by courts of equity, under the rules governing such proceedings, and upon the execution of proper bond against damages for an injunction improvidently granted and a showing that the danger of irreparable loss or damage is immediate, a preliminary injunction may issne . . . .

15 U.S.C. $\$ 26$ (1982 \& Supp. 1985) (codifying section 16 of the Clayton Act). Due to the volatile nature of the financial inarkets, a prelininary injunction effectively destroys a merger in inost instances.

3. 47 Fed. Reg. 28,493 (1982). 
Clayton Act. ${ }^{4}$ The 1982 Guidelines (and their 1984 revisions) represent a marked shift in enforcement policy. ${ }^{5}$ The Guidelines enbody a policy of prosecutorial restraint exercised to promote the realization of potential efficiency gains through merger. ${ }^{6}$ This new enforcennent posture has altered the government's position as the primary implennentor of merger policy. ${ }^{7}$

The Justice Department's einphasis on potential efficiencies has led to a serious decline in the number of mergers challenged under the new Guidelines. Of the 7,828 mergers reported under Hart-Scott-Rodino between 1982 and 1986, the enforcement agencies requested additional information on only $4.4 \%$ and brought enforcement actions against only $0.7 \%$ of the transactions. ${ }^{8}$ In $1986,2,406$ mergers were reported, up from 868 in 1979 when stricter guidelines had generated an additional information request rate of $12.6 \%$ and an enforcement action rate of $2.3 \% .^{9}$

4. 15 U.S.C. $\S 18$ (1982) (codifying section 7 of the Clayton Act). Under the Hart-ScottRodino Amendments, merging firms must file reports with the Justice Department [hereinafter "Department"] that contain specific information about their operations and the transaction. The Department evaluates the confidential information under its guidelines and, if the merger raises "concern," may issue a request for additional information. The merging parties respond with specific answers to the Department's concerns or may restructure their transaction to alleviate its anticompetitive effects, usually by arranging to divest certain units of the merged firm. A particular merger will fall within the jurisdiction of the Federal Trade Commission if it occurs in an industry for which the Commission has developed expertise. See Jorde, Restoring Predictability to Merger Guidelines, 4 CONTEMP. PoL'y ISSUES 1,9 \& n.19 (1986).

5. U.S. Dep't of Justice, Statement Accompanying Release of the Revised Merger Guidelines, 49 Fed. Reg. 26,823 (1984) (claiming that revised guidelines clarify and refine the Department's sensitivity to market realities, first articulated in the 1982 guidelines). For academic criticism, analysis, and defense of the shift, see generally Baxter, Responding to the Reaction: The Draftsman's View, 71 CALIF. L. Rev. 618 (1983); Harris \& Jorde, Market Definition in the Merger Guidelines: Implications for Antitrust Enforcement, 71 CALIF. L. REV. 464 (1983); Harris \& Sullivan, Horizontal Merger Policy: Promoting Competition and American Competitiveness, 31 ANTTTRUST BULl. 871 (1986).

Although technically intended as a device to determine the distribution of litigation resources within the Antitrust Division, the guidelines actually have wider impact on merger policy. See generally Kauper, The 1982 Horizontal Merger Guidelines: Of Collusion, Efficiency, and Failure, 71 CALIF. L. REv. 497, 502 (1983) (discussing applications of the guidelines).

6. See U.S. Dep't of Justice, supra note 5, at 26,826 ("In practice, the Department never ignores efficiency claims."); Baxter, supra note 5 (symposium comments of Antitrust Division chief); see also Harris \& Jorde, supra note 5 (market defimitions and concentration levels raised to ensure that few efficiency-producing mergers will be denied).

7. The new enforcement posture has met with the criticism of commentators, see, e.g., Harris \& Jorde, supra note 5; Harris \& Sultivan, supra note 5; Litvack, Government Antitrust Policy: Theory Versus Practice and the Role of the Antitrust Division, 60 TEX. L. REv. 649, 654-55 (1982); Miller, Notes on the 1984 Merger Guidelines: Clarification of the Policy or Repeal of the Celler-Kefauver Act?, 29 ANTITRUST BULL. 653 (1984), as well as the increased scrntiny of Congress, see, e.g., P. Rodino, News Release: Rodino Announces Hearings to Consider Impact of Antitrust Cutbacks on U.S. Competitiveness (Feb. 25, 1987) (Chairman, House Committee on Judiciary).

8. P. Rodino, supra note 7, at 4.

9. Id. Similarly, additional requests by the FTC resulted in voluntary abandonment of the 
Driven by a concern that the Department's failure to identify anticompetitive mergers has led to the "merger madness" characteristic of the early 1980's, non-traditional players have entered the enforcement arena. Concerned that the new policy fails to consider the local effects of mergers, state governments liave become active in reviewing proposed mergers. ${ }^{10}$ The shift in policy has also caused an increase in the number of suits brought by private enforcers of antimerger law, particularly competitors. ${ }^{11}$

As firms began to seek injunctive relief from the anticompetitive mergers of their rivals, the Department began to counsel courts through ainicus briefs, pushing them to confront the propriety of granting such a remedy to competitors of the merging firms. The Department argues tliat a competitor should have hittle interest in enjoining an anticoinpetitive merger. ${ }^{12}$ An anticompetitive merger would raise a price umbrella over the industry, so tlie argument runs, thereby bringing supracoinpetitive profits to the remaining coinpetitors as well as to the merged firm; enjoining such a merger, therefore, would be contrary to the interests of a rational self-interested coinpetitor. The Department believes that a rational competitor would seek instead to enjoin only those mergers that yield efficiencies to tlie merged firm-efficiencies that will be reflected in

transaction in $0.95 \%$ of the cases reported in $1979-80$, but in only $0.24 \%$ percent of the cases reported betweeu $1982 \&$ 1986. Id.

10. See, e.g., Horizontal Merger Guidelines of the National Association of Attorneys General, Antitrust \& Trade Reg. Rep. (BNA) No. 1306, Speeial Supp. (Mar. 10, 1987) [hereinafter "State Guidelines"] (associatiou announces uniform guidelines under which states will seek section 7 enforcement in their antitrust capacity as parens patriae). These guidelines adopted approaches to market definition and efficiencies recommended in two articles critical of the guidelines. See Harris \& Jorde, Antitrust Market Definition: An Integrated Approach, 72 CALIF. L. REV. 1 (1984); Fisher \& Lande, Efficiency Considerations in Merger Enforcement, 71 CALIF. L. REv. 1580 (1983).

11. All of the cases dealing with competitor standing to enjoin a merger of rivals that predate Cargill parallel the shift in Justice Department policy toward a heightened sensitivity for potential efficiency gains through inerger. See Monfort of Colorado, Inc. v. Cargill, Inc., 761 F.2d 570, 577 (10th Cir. 1985) (finding only threc recent private plaintiff cases, all brought since the latest guideline revisions-Cia. Petrolera Caribe, Inc. v. Arco Carribean, Inc., 754 F.2d 404, 407-08 (1st Cir. 1985); Christian Schunidt Brewing Co. v. G. Heileman Brewing Co., 753 F.2d 1354 (6th Cir.), cert. dismissed, 469 U.S. 1200 (1985); Chrysler Corp. v. General Motors Corp., 589 F. Supp. 1182 (D.D.C. 1984)), rev'd, 107 S. Ct. 484 (1986). Reported cases indicate only one subsequent competitor-generated challenge to a merger, White Consol. Indus. v. Whirlpool Corp., 612 F. Supp. 1009 (N.D. Ohio), injunction vacated, 619 F. Supp. 1022 (N.D. Ohio 1985), aff'd, 781 F.2d 1224 (6th Cir. 1986) (parties agreed to restructure transaction in response to court's initial finding), and one competitor action for post-merger divestiture, Arthur S. Langenderfer, Inc. v. S.E. Johnson Co., 729 F.2d 1050 (6th Cir.), cert. denied, 469 U.S. 1036 (1984).

12. Department of Justice Brief as Amicus Curiae, Monfort of Colorado, Inc. v. Cargill, Inc., 761 F.2d 570 (10th Cir. 1985) (Nos. 83-2588 \& 84-1305), rev'd, 107 S. Ct. 484 (1986). See also Werden, Challenges to Horizontal Mergers by Competitors Under Section 7 of the Clayton Act, 24 AM. BuS. L.J. 213 (1986) (Justice Department economist presenting theory in opposition to competitor standing). 
a lower market price and, consequently, a slimmer profit margin for the plaintiff.

The Supreme Court addressed the issue of competitor standing in Cargill, Inc. v. Monfort of Colorado, Inc., during its 1986 Tern..$^{13}$ In Cargill the Court held that a competitor's right under section 7 of the Clayton Act to seek the injunction of a merger was prefaced upon its ability to show "antitrust injury," a standing requirement that had been developed for private plaintiffs seeking treble damages under section 4 of the Clayton Act. ${ }^{14}$ Although the Court did not specifically foreclose a competitor's ability to enjoin a merger, many antitrust attorneys agree with the dissent's conclusion that the injury requirement irreparably frustrates competitor standing. ${ }^{15}$ In this Comment I challenge the dissent's conclusion: competitor standing survives Cargill, although adequate standards to test Clayton Act injury have yet to be designed.

While the Court's analysis in Cargill was somewhat cursory, the case does not foreclose competitor enforcement of the Clayton Act's antimerger provision. The holding in Cargill requires an analysis of the legislative intent underlying section 7 . The legislative history of the Clayton Act reveals that Congress recognized that inergers can injure competitors as well as competition. The legislators designed the antimerger provision to protect competitors from such harm. Merger lawyers face the challenge of finding an analytical framework to identify that harm. Modern business theorists have developed new methods of analyzing firm behavior and the commercial environment, inethods that can help courts and competitors to identify those mergers that will injure rival firms in ways Congress intended to prevent.

My argument that Cargill's injury requirement is not inimieal to competitor standing will proceed in two stages. First, I will propose a definition of Clayton Act antitrust injury; second, I will employ strategic behavior theory to identify the competitors of merged firns who will suffer such injury. In Part I, I review the legislative history of the Clayton Act and the case law construing the Act's standing provision to develop a proposed standard of antitrust injury. After analyzing Cargill and concluding that the opinion fails to address the range of injuries a competitor might suffer due to a merger of its rivals, I examine the legislative history of the Clayton Act to identify the injuries it was designed to prevent. In Part II, I discuss strategic behavior analysis-a new method of understanding markets and competitors-and determine that it is an approach

13. 107 S. Ct. 484 (1986).

14. 15 U.S.C. $\S 15$ (1982) (codifying section 4 of the Clayton Act).

15. Cargill, 107 S. Ct. at 496 n.1; Telephone Interview with Maureen McGuirl, Partner, Gibson, Dunn and Crutcher, Los Angeles (Jan. 1987) (discussing practical frustrations resulting from Cargill). 
well-suited to a Court's determination of injury to competitors. In Part III, I illustrate how market structure and strategic behavior allow a merged firm to lessen competition and imjure competitors in ways contrary to the poticies embodied in the Clayton Act. I conclude by presenting hypothetical mergers to illustrate how strategic behavior analysis can aid a plaintiff in meeting the proposed standard for Clayton Act antitrust injury.

I

\section{STANDing Under Section 7 of the Clayton Act}

The issue of competitor standing in merger hitigation arises out of constitutional standing doctrine. Generally, standing principles attempt to insure that a particular plaintiff is a member of a class that the law seeks to protect. ${ }^{16}$ In antitrust, the issue takes on special importance because of a judicial concern for the potential overinclusiveness of section 4 of the Clayton Act, the provision extending private parties standing to enforce the antitrust laws. ${ }^{17}$

In Brunswick Corp. v. Pueblo Bowl-O-Mat, Inc. ${ }^{18}$ the Supreme Court concluded that section 4 did not empower a private party to recover for every economic loss attributable to conduct the antitrust laws condemn. In Brunswick, respondent bowling alley operator claimed that it was entitled to the monopoly profits that it would have earned had Bruuswick not acquired a rival operator, thereby preventing the rival from going out of business. ${ }^{19}$ Finding that the defendant had actually enhanced rather than lessened competition, the Court established the requirement that a plaintiff may be awarded treble damages ouly if the defendant injured it in a inanner contrary to congressional design. ${ }^{20}$

The Brunswick opimion did not resolve the standing issue, however. Although the Brunswick Court set out a specific injury requirenent, it did not address the additional factors considered under the various standing tests already being apphed in the circuit courts. The issue reached the Supreme Court in Associated General Contractors, Inc. v. California State Council of Carpenters. ${ }^{21}$ To resolve the confusion of lower courts attempting to fit standing and injury requirements into a single coherent structure designed to serve the central goal of identifying

16. Cia. Petrolera Caribe, Inc. v. Arco Caribbean, Inc., 754 F.2d 404, 407 (1st Cir. 1985).

17. Associated Gen. Contractors, Inc. v. California State Council of Carpenters, 459 U.S. 519, 529 (1983) ("A literal reading of [section 4] is broad enough to encompass every harm that ean be attributed directly or indirectly to the consequences of an antitrust violation."). Section 4 empowers private attorneys general to enforce the antitrust laws. See 15 U.S.C. $\S 15$ (1982).

18. 429 U.S. 477 (1977).

19. Id. at 488 .

20. Id. at 489 .

21. 459 U.S. 519 (1983). 
appropriate antitrust plaintiffs, ${ }^{22}$ the Supreme Court combined the injury requirement with the concerns reflected in the circuit court standing tests to arrive at a multifactor standing analysis. The Court held that a plaintiff seeking to estabhish that it is a proper party to bring a private antitrust action must demonstrate five factors: (1) that a causal connection exists between the antitrust violation and the harm to the plaintiff; (2) that the defendant intended to cause that harm; (3) that the harm is a type of injury the antitrust laws were designed to forestall ("antitrust injury"); (4) that no more directly injured party exists to redress the violation; and (5) that the danages are not highly speculative. ${ }^{23}$ As the Seventh Circuit later observed, the Associated General Contractors Court concluded that "a determination of antitrust standing should focus not only on whether there has been an 'antitrust injury,' but also on whether the particular plaintiff is the appropriate antitrust enforcer."24

With standing under section 4 as a background, Cargill, Inc. $v$. Monfort of Colorado, Inc. ${ }^{25}$ required the Court to determine whether a horizontal competitor of two merging firms was the appropriate party to seek injunction of a merger under section 16 of the Clayton Act. ${ }^{26}$ In this Part, I argue that Cargill does present a full treatment of the standing issues that arise when a competitor seeks to prevent a merger of rivals. Dissecting Cargill, I conclude (1) that antitrust injury is the only Associated General Contractors factor relevant to standing under section 7; (2) that the Court refused to foreclose any theory of coinpetitor injury because Chicago School theories of rational profit inaximizing behavior do not account for every motivation inspiring firm behavior; and (3) that when Cargill is viewed in hight of the Clayton Act's legislative history, it does not stand for the proposition that the competitor injuries contemplated by Congress can be remedied through post-merger enforcement of the Sherman Act. I then analyze the concerns traditionally identified in the legislative history in order to define the distinct set of competitor injuries Congress designed the Clayton Act to prevent. The history reveals that the legislators' concept of injury to competitors was based in the economic model through which they viewed competition-a model in which competitors play an integral part in the distribution of resources and the promotion of progress. Their concern was that merger and concentration could impair the commumicative nature of transactions and

22. See, e.g., Ostrofe v. H.S. Crocker Co., 670 F.2d 1378, 1386-88 (9th Cir. 1982), vacated, 460 U.S. 1007 (1983) (vacated and remanded "for further consideration in light of" Associated General Contractors); In re Indus. Gas Antitrust Litig., 681 F.2d 514 (7th Cir. 1982), cert. denied, 460 U.S. 1016 (1983).

23. See In re Indus. Gas, 681 F.2d. at $537-45$ (interpreting Associated General Contractors).

24. Id. at 526 .

25. 107 S. Ct. 484 (1986).

26. 15 U.S.C. $\S 26$ (1982 \& Supp. 1985). 
might thereby injure competitors as well as the competitive process. In those circumstances, Congress intended to protect both the process and its participants. I conclude the Part by applying case law and the lessons of the legislative history to propose a standard for determining whether a competitor has standing to seek injunction of a merger of its rivals.

\section{A. Cargill, Inc. v. Monfort of Colorado, Inc.}

Monfort sued under section 16 of the Clayton Act to enjom Excel, a subsidiary of Cargill, from acquiring Spencer Beef, a division of the Land O'Lakes Agricultural Cooperative. Monfort, Excel and Spencer each operated beef-packing plants in the Midwest. The plants integrated facilities for the slaughter and packaging (termed "fabrication") of beef. Because not all firms integrated slaughtermg plants with fabrication facilities, the trial court identified two relevant markets in which market shares, and thus concentration levels, differed. ${ }^{27}$ The three firms were found to compete in the Midwest for fed cattle (the input market) and nationally for purchasers of fabricated beef (the output market). ${ }^{28}$

\section{Standing Issues}

Because standing is a threshold requirement, the Supreme Court did not address the concentration evidence analyzed by the District Court. ${ }^{29}$ Although such substantive issues do play a part in standing analysis, the legality of the merger itself is not formally considered. In terms of the Clayton Act, the antitrust injury requirement forces the plaintiff to present a plausible claim that, assuming the merger is illegal, the plaintiff will be injured as a direct result of that illegality in a way Congress intended to prevent. ${ }^{30}$

In Cargill the Court noted that it lad not previously considered "whether a private plaintiff seeking an mjunction under section 16 of the Clayton Act must show a threat of antitrust injury."31 The Court turned to the source of the injury requirement, section 4 of the Clayton Act, and

27. Cargill, 107 S. Ct. at 487.

28. Id. at 487 n.2.

29. The district court accepted Monfort's determination of market share. Monfort of Colorado, Inc. v. Cargill, Inc., 591 F. Supp. 683,706 (D.C. Colo. 1983). After the merger, Excel would still be the second largest firm in both markets, although its share of each would have grown to nearly equal that of the largest firm, IBP. In the input market, the aggregate of the market shares of the four largest firms ("CR4") would rise from $52.0 \%$ to $57.5 \%$ and the combined market share of Excel and IBP would be $44.8 \%$. Id. In the output market, the CR4 would increase from $53.8 \%$ to $59.5 \%$ and Excel and IBP would account for $47.7 \%$ of that market. Id. The district court found that the statistical evidence suggested that the merger would result in a significant increase in industry concentration and should thus be presumed illegal. Id. at 709-10.

30. See Christian Schmidt Brewing Co. v. G. Heileman Brewing Co., 753 F.2d 1354, 1358, cert. dismissed, 369 U.S. 1200 (1985) (cited with approval in Cargill, 107 S. Ct. at 490 n.7.)

31. $107 \mathrm{~S}$. Ct. at 488 ; see also supra note 2. 
surveyed the cases construing and confirming "the importance of showing antitrust injury." 32 The Court then coinpared the language of section 4 with that of section 16 and observed that although the requirements of section 4 and section 16 differed shightly, ${ }^{33}$ both contained similar wording concerning the relationship of the injury to the violation of the antitrust laws. ${ }^{34}$ The Court adopted lower court reasoning that required section 16 plaintiffs to "allege an mjury of the type the antitrust laws were designed to prevent." 35 The majority supported its conclusion with reference to statements in the legislative history that are "consistent with the view that section 16 affords private plamtiffs injunctive relief only for those injuries cognizable under section $4 .{ }^{\prime 36}$

Although the text of the opinion does not discuss what factors other than "antitrust injury" a plaintiff must show to have standing under section 16, the Court twice noted that the injunctive remedy which the provision estabhishes shapes the requirements of antitrust standing. The Court noted that the Associated General Contractors concern for preventing duplicative recovery is not relevant to a section 16 analysis because "100 injunctions are no more effective than one." 37 Inphicitly, therefore, the requirement that the plaintiff be the party most directly injured by the violation is also irrelevant because the defendant bears no risk of inultiple liability. ${ }^{38}$ Furtliermore, as the Cargill Court noted, the merging parties' intent to beliave in ways contrary to antitrust law is also irrelevant to standing in this setting because the Clayton Act's merger provision addresses market structures that create the potential for anticompetitive abuse, regardless of intent. ${ }^{39}$

By approving an opinion of the Third Circuit Court of Appeals

32. Cargill, 107 S. Ct. at 489 (citing Associated Gen. Contractors, Inc. v. California State Council of Carpenters, 459 U.S. 519 (1983); Blue Shield of Virginia v. McCready, 457 U.S. 465 (1982); Brunswick Corp. v. Pueblo Bowl-O-Mat, Inc., 429 U.S. 477 (1977)).

33. The Court noted that section 4 requires that the injury be to business or property, while section 16 contains no such limitation. Under section 4, the party would have to show that the injury had occurred; under section 16 , it would only need to show that the injury was "threatened." Cargill, $107 \mathrm{~S}$. Ct. at $489-90$.

34. Id. at 490 ("Section 4 requires proof of injury "by reason of anything forbidden in the antitrust laws;' $\S 16$ requires proof of 'threatened loss or damage by a violation of the antitrust laws.' ")

35. Id.

36. Id.

37. Id. at 490 n.6.

38. See Illinois Brick Co. v. Illinois, 431 U.S. 720 (1977) (holding that the difficulty of calculating damages to avoid duplicative recovery limits the class of consumers who may recover monopoly overcharge to direct purchasers-a party who contracted with a brick layer who supplied monopoly priced bricks does not have standing to recover the overcharge).

39. In lengthy footnotes, the Cargill Court stated that standing could rest on a showing that post-merger market structure would provide the defendant with an ability to price predatorily. Intent was not discussed. See $107 \mathrm{~S}$. Ct. at $494-95 \mathrm{nn} .15$ \& 17; see also infra text accompanying notes 71-130 (discussing congressional focus on market structures and firm position). 
specifying those factors relevant to standing to enforce section 7 , the Court did provide soine additional guidance. In Schoenkopf $v$. Brown \& Williamson Tobacco Corp. ${ }^{40}$ a section 16 non-merger case, the Third Circuit acknowledged that courts had applied a "lower threslold standing requireinent" for section 16 injunctions than for section 4 damages. The Third Circuit derived its conclusion from the same distinctions between section 16 and section 4 that the Cargill Court would later identify. ${ }^{41}$ The Third Circuit concluded that the lesser requirements of standing to seek injunctive relief of a inerger depended only upon a slowing of antitrust injury proximately caused by the defendant's planned acquisition, rather than upon a more thorough enumeration of the factors set out in Associated General Contractors. ${ }^{42}$

In light of the Cargill Court's approval of the Schoenkopf formulation of standing, the Cargill analysis of antitrust injury is effectively a discussion of the showing a private party inust make in order to establish standing to sue for injunctive relief under section 16 . In short, to establish standing a private plaintiff inust allege only "threatened loss or dainage 'of the type the antitrust laws were designed to prevent." " 43

\section{Injury Issues}

In discussing Clayton Act injury, the Cargill Court recognized that an anticompetitive inerger inay injure a coinpetitor of the inerging firms in ways Congress intended to prevent. The Court refused to adopt the governinent's Chicago School position, which would have substantially restricted the injuries sufficient to warrant standing.

In its original form, as contained in the Justice Department's amicus brief to the Tenth Circuit, the government's argument reflected a theory Judge Easterbrook had published regarding a theoretical coinpetitor's inotives for preventing the merger of two rivals. ${ }^{44}$ Easterbrook argued that since the antitrust laws are designed to prevent the exertion of market power, and since market power allows a firm to raise the price of its product, an illegal merger would bestow greater profits on all firms in the merging firms' market. Alternatively, if the merger created efficiencies for the newly merged firm, allowing that firm to lower its prices, then the motivation of a rival seeking to enjoin the merger would be the improper

40. 637 F.2d 205 (3d Cir. 1980).

41. Compare Cargill, 107 S. Ct. at 490 nn.6-7 with Schoenkopf, 637 F.2d at 210.

42. Schoenkopf, 637 F.2d at 210 (citing Brunswick Corp. v. Pueblo Bowl-O-Mat, Inc., 429 U.S. 477,489 (1977)).

43. Cargill, $107 \mathrm{~S}$. Ct. at 491 (quoting Brunswick, 429 U.S. at 489).

44. See Easterbrook, The Limits of Antitrust, 63 TEx. L. REv. 1, 36 (1984). Easterbrook suggests using the plaintiff's business relationship to the defendant as a "filter" for antitrust standing. One permutation of this filter would deny any competitor standing to enjoin the horizontal merger of its rivals. Id. 
one of preserving a less competitive market. ${ }^{45}$ Accordingly, Easterbrook argued against empowering a firm to prevent a merger of two its rivals.

By the time the issue reached the Supreme Court, the government had softened Easterbrook's argument. Rather than asking the Court to bar an entire class of section 7 plaintiffs, the governinent urged the Court to apply Easterbrook's logic to narrow the range of claims a competitor could allege to establish standing in response to Monfort's implicit allegation of injury through predatory pricing. The government argued that a per se rule against competitor use of predatory pricing allegations to establish antitrust injury in inerger litigation was justified by a coinpetitor's strong incentive to prevent procompetitive mergers, the evidentiary problems of proving a prospective predatory pricing strategy, and the ability of a victim to seek post-merger damages. ${ }^{46}$

While techmically refusing to consider Monfort's predatory pricing allegation because the plaintiff had not raised the issue at trial, the Court did respond to the Department's suggestion. In lengthy footnotes the Court stated that, as a threshold requirement, a coinpetitor could establish standing by showing that the challenged merger would give rise to a 1narket structure conducive to predatory pricing. ${ }^{47}$ The Court thus rejected the per se rule the Department suggested. In so doing, the Court implicitly recognized that Chicago School models of competitors' rational pursuit of profits and efficiencies do not explain all firm behavior. $^{48}$ Other motivations could lead a firm to challenge a merger of

\footnotetext{
45. Echoing Easterbrook, the government's brief argued:

What legitimate complaint could a competitor have to a merger? The goal of the merger must either be efficiency or power. If it is efficiency, competitors may be hurt; the new firm, having cut costs, may cut prices. But an efficiency gain should not be an antitrust violation. And, even if, despite the efficiency, the merger were held to violate, the injury suffered by a competitor would not be an antitrust injury; it would not be an injury the competitor would be entitled to redress. If, on the other hand, the merger were aimed at market power, the merger might then be unlawful, but no competitor would be injured. Such a merger would help competitors by placing a price umbrella over their heads.
}

Dep't of Justice Brief as Amicus Curiae, Monfort of Colorado, Inc. v. Cargill, Inc., 761 F.2d 570 (10th Cir. 1985) (Nos. 83-2588 \& 84-1305), rev'd, 107 S. Ct. 484 (1986); see also Note, Horizontal Mergers, Competitors, and Antitrust Standing Under Section 16 of the Clayton Act: Fruitless Searches for Antitrust Injury, 70 MinN. L. REv. 931, 940-41 (1986).

46. Amicus Curiae Brief of the United States Department of Justice, Cargill, 107 S. Ct. 484 (1986) (No. 85-473); see also Werden supra note 12.

47. Cargill, $107 \mathrm{~S}$. Ct. at $494-95 \mathrm{nn} .15$ \& 17 (predator must have: (1) capaeity to absorb shares of rivals once prices have been cut; (2) resources to maintain the strategy until rivals fail; and (3) sufficient power through market share and structure to sustain monopoly prices long enough after rivals fail to recoup losses and reasonable profit).

48. Similar rejections can be found in other section 7 standing cases. See Christian Schmidt Brewing Co. v. G. Heileman Brewing Co., 753 F.2d 1354, 1357 (6th Cir.) (rejecting suggestion that power meant higher profit for all and thus no injury), cert. dismissed, 469 U.S. 1200 (1985); White Consol. Indus., Inc. v. Whirlpool Corp., 612 F. Supp. 1009, 1015 (N.D. Ohio 1985) ("[M])tivation for the filing of the lawsuit is not particularly relevant to the inquiry triggered by the lawsuit: the potential anti-competitive effects of the transaction in the relevant product markets."), vacated, 619 F. Supp. 1022 (N.D. Ohio 1985), aff'd, 781 F.2d 1224 (6th Cir. 1986). 
rivals.

\section{Cargill as a Guide to Standards of Clayton Act Injury}

Cargill does not stand for the proposition that Clayton Act injury is limited to post-merger injuries contemplated by the Sherman Act. The dissent in Cargill correctly observed that the majority focused on post1nerger conduct, "reduc[ing] to virtual irrelevance the related but distinct issue of the legality of the inerger itself." 49 The dissent erroneously concluded, however, that this focused analysis effectively forecloses injunctive rehef for a private party unless it can show actual or probable postinerger conduct of a type actionable under the Sherman Act. ${ }^{50}$ Case law and the legislative history of the Clayton Act both show that the prophylactic antinerger provision addresses a set of injuries beyond those proscribed by the Sherman Act's condemnation of agreeinents in restraint of trade.

The Cargill opinion lacks a statement of the bounds of Clayton Act injury because the plaintiff failed to present a predatory pricing claim founded in the structural characteristics of the beef processing industry. The Supreme Court concluded that if the plaintiff's highly speculative theory proved true, the injury would be better redressed after the merger under the Sherman Act. ${ }^{51}$ The Court was able to concentrate on standing doctrine under section 16 without determining whether a credible predatory pricing claim would meet an injury standard appropriate to the purposes of the Clayton Act's antinerger provision. As a result of its circuinscribed inquiry, the Court flatly stated that a showing of antitrust injury was required by section 16: "It would be anomalous, we think, to read the Clayton Act to authorize a private plaintiff to secure an injunction against a threatened injury for which he would not be entitled to compensation if the injury actually occurred." 52 The Court confirmed this proposition with references to similar statements in the legislative history of the injunctive relief provision. The Court's conclusion is incomplete, however, because the statements supporting it pre-date the amendments that produced the current substantive prohibition of anticompetitive mergers. The majority conclusion that "sections 4 and 16 are thus best understood as providing complinentary remedies for a sin-

49. Cargill. 107 S. Ct. at 496 n.1 (Stevens, J., dissenting).

50. Id. The Sherman Act prohibits monopolization, attempts to monopolize, and agreements in restraint of trade. 15 U.S.C. $\S \S 1,2$ (1982 and 1985 Supp.). Its standards of proof is much higher than that of the Clayton Act. See infra text accompanying note 63.

51. The Tenth Circuit had labelled Monfort's claim an allegation of predatory pricing. Cargill, $107 \mathrm{~S}$. Ct. at 494 n.14. Monfort described a strategy whereby the merged Excel would bid up the price for inputs and cut the price for outputs in an attempt to gain share from both IBP and the smaller firms. Id. at 491.

52. Id. at 490 . 
gle set of injuries" does not reflect a full consideration of congressional intent in providing injunctive relief from anticompetitive mergers. ${ }^{53}$

Had the Court been pushed to define the limits of Clayton Act injury, it would have had to reconcile the purposes for the remedial provision with the substantive prohibition the remedy was designed to support. A systematic inquiry would have revealed that injunctive relief may be proper where an award of damages is not. In Cargill, the Court acknowledged that Brunswick was not directly on point because the plaintiff there had sought section 4 treble-damages for a merger alleged to have violated section $7 .^{54}$ The Brunswick opiniou had noted that the prophylactic nature of section 7 frustrated any attempt to apply a section 4 damage reinedy. ${ }^{55}$ While the Brunswick Court found that the plaintiff's clain of windfall profits was inimical to the antitrust goal of "protect[ing] competition, not competitors,"

Every merger ...., whether lawful or unlawful, has the potential for producing economic readjustments that adversely affect some persons. But Congress has not condemned mergers on that account; it has condemned them only when they may produce anticompetitive effects... [section 4 damages for every readjustment caused by unlawful mergers would be] entirely fortuitous. . . . Of course, Congress is free, if it desires, to mandate damages awards for all dislocations caused by unlawful mergers despite the peculiar consequences of so doing. But because of these consequences, "we should insist on a clear expression of congressional purpose," [citation omitted] before attributing such an intent to Congress. ${ }^{57}$

The Brunswick Court's discussion denonstrates that injury analysis is frustrated when the reinedy a party seeks to enforce is not the primary remedy Congress considered when designing a particular prohibition. Brunswick shows that section 7 addresses specific prospective concerns regarding inarket structure, and that section 4 may be unable to remedy all of those concerns because dainages merely restore the financial position of coinpetitors without restoring the structure of the market. The prophylactic reinedy of section 16 injunctions is better suited to protect developing market structures. Brunswick thus weakens the Cargill Court's conclusion that the reinedies provided in section 4 and section 16 are complinentary. Furthermore, by stressing the purposes of section 7 , Brunswick shows that injury analysis inust be tied to the congressional

53. Id. at 491 .

54. Id. at 489.

55. Brunswick Corp. v. Pueblo Bowl-O-Mat, Inc., 429 U.S. 477, 485 (1977) ("Section 7 of the Act proscribes mergers whose effect 'may be substantially to lessen competition, or to tend to crcate a monopoly.' ") (emphasis added by Court).

56. Id. at 488 (quoting Brown Shoe Co. v. United States, 370 U.S. 294, 320 (1962)).

57. Id. at 487-88 (citing Hawaii v. Standard Oil Co., 405 U.S. 251, 264 (1972)). 
intent behind the substantive provision under which the plaintiff seeks relief. ${ }^{58}$ Consequently, because the Cargill Court focused exclusively on the legislative history of the remedial provision, its injury analysis is incoinplete.

Other courts confronted with section 7 standing issues have evaluated the legislative history and concluded, as did Justice Stevens in dissent in Cargill, that Congress designed the provision as a prophylactic measure to prevent threats to competition by "certain trade practices which ... singly and in themselves" do not violate the Sherman Act. ${ }^{59}$ As Justice Stevens observed, "Congress concluded that the Sherman Act's prohibition against mergers was not adequate."

The legislative history reveals that the Celler-Kefauver annendinents, which form the current version of section 7, were designed to respond to a Supreine Court interpretation of the Clayton Act that allowed merging firms to circumvent its prohibition of anticompetitive inergers by exchanging assets rather than stock. ${ }^{61}$ Congress found that

58. See Ostrofe v. H.S. Crocker Co., 670 F.2d 1378, 1387 (9th Cir. 1982) ("The central theme of Brunswick is that to be actionable under Section 4, plaintiff's injury should fall within the core of congressional concern underlying the substantive provision of the antitrust laws allegedly violated."), vacated, 460 U.S. 1007 (1983) (judgment vacated and remanded for reconsideration in light of Associated General Contractors). A court critical of Crocker agreed that congressional intent as to the substantive prohibitions defined actionable injury, but argued that the Ninth Circuit had misidentified congressional concerns underlying the antitrust statute there at issue. See In re Indus. Gas Antitrust Litig., 681 F.2d 514 (7th Cir. 1982), cert. denied, 460 U.S. 1016 (1983).

59. Cargill, 107 S. Ct. at 496 n.2 (Stevens, J., dissenting) (quoting S. Rep. No. 698, 63d Cong., 2d Sess. 1 (1914)); see, e.g., Brown Shoe Co. v. United States, 370 U.S. 294 (1962); see also Schwartz, The New Merger Guidelines: Guide to Governmental Discretion and Private Counseling or Propaganda for Revision of the Antitrust Laws?, 71 CALIF. L. REv. 575, 600 (1983) (Congress' express intent in 1914 and again in 1950 was to "cast the anti-merger net more widely" than had the Sherman Act).

As Professor Schwartz notes, documenting these differences has become necessary because of conservative antitrust theorists' suggestion that the standards of legality under the two acts have been merged. Id. at 600 . Schwartz notes that the introductory statement of principles to the Merger Guidelines lumps the standards together as if they are one in the same. Perhaps this trend gave Justice Stevens cause to dissent so emphatically in Cargill from an issue the Court did not directly confront; perhaps he feared the precedential impact of the Court's post-merger focus and its broad statements respecting the complementary nature of sections 4 and 16. See supra notes $49-53$ and aecompanying text.

60. Cargill, 107 S. Ct. at 496 (Stevens, J., dissenting) (citing S. Rep. No. 698, 63d Cong., 2d Sess. 1 (1914)); see also S. Rep. No. 1775, 81st Cong., 2d Sess. 4 (1950).

In presenting the Celler-Kefauver Amendments to the Senate, Sen. Kefauver stated:

Let me say that if the Members of Congress at that time had thought the Sherman Act was sufficient in the beginning they never would have passed the Clayton Act. This amendment is obviously necessary in order to give effect to the intention of the Congress at that time.

96 Cong. Rec. 16,453-54 (1950); see also id. at 16,506-07 (statement of Sen. O'Connor); 95 Cong. REC. 11,493 (1949) (statement of Rep. Carrol); id. at 11,496-97 (statement of Rep. Boggs); id. at 11,493 (statement of Rep. Yates).

61. 96 CONG. REc. 16,452 (1950) (statement of Sen. Kefauver); id. at 16,433 (statement of Sen. O'Connor); 95 CONG. REC. 11,484 (1949) (statement of Rep. Celler). 
the complex proof requirements of the Sherman Act did not address its concerns regarding the restructuring of markets caused by illegal mergers. ${ }^{62}$ Congress broadened the coverage of section 7 to include all forms of merger and acquisition so that the effects of such transactions would be evaluated under the "substantially to lessen competition" standard found in the Clayton Act rather than the "in restraint of trade" standard found in the Sherman Act. ${ }^{63}$ The Clayton Act, therefore, addresses an additional set of antitrust injuries that result not from a restraint of trade, but from a substantial reduction $\mathrm{m}$ competition in a manner that Congress sought to proscribe. Strict Sherman Act analysis of Clayton Act injury can not remedy these additional injuries.

While the legislative history and case law do not require that every firm in a market restructured by an illegal merger have standing to enjoin that merger, they do demonstrate that some competitors will suffer actionable injury due to structural changes in the market. Justice Stevens' dissent to Cargill underscored the principle that "a competitor trymg to stay in business in a changing market must have standing to ask a court to set aside a merger that has changed the character of the market in an illegal way." 64 But Justice Stevens and the majority did not develop two features essential to a complete analysis of the injury such a competitor will suffer. To determine whether a plaintiff has standing, a court must first scrutinize the alleged injury to assure that it is a type of injury that the Clayton Act was designed to prevent. Then that court must inquire whether the likehhood of injury in the post-merger inarket is high enough to give rise to concern under the model Congress established in the Clayton Act. In the sections below, I suggest standards for assessing alleged antitrust injuries under each of these inquiries.

\section{B. Antitrust Injury, the Clayton Act, and Congressional Intent}

The debate surrounding the legislative policies embodied in the anti-

62. 95 CoNG. REC. at 11,493 (1949) (statement of Rep. Yates) (post-merger Sherman Act proceedings frustrate desired relief, dissolution is difficult, market has been damaged once competition between the merged firms is eliminated and properties and technologies become commingled); 96 CoNG. Rec. at 16,434 (1950) (statement of Sen. O'Connor); see also Brown Shoe, 370 U.S. at 315 ("Congress rejected, as inappropriate to the problem it sought to remedy, the application to $\S 7$ cases of the standards for judging the legality of business combinations adopted by the courts in dealing with cases arising under the Sherman Act"); Davidson, The Competitive Significance of Segmented Markets, 71 CALIF. L. REV. 445, 447 (the prophylactic measure was intended to prevent "harms to competition that are encouraged by a concentrated market structure and that either cannot be deteeted or, if detected, cannot be eliminated by rules establishing permissible competitive conduct").

63. 96 CONG. REC. 16,452 (1950) (statement of Sen. Kefauver) (citing United States v. Columbia Steel Co., 334 U.S. 495 (1948) (merger of mammoth U.S. Steel to gain large share in new area found not to be an "unreasonable restraint of trade," and thus did not violate the Sherman Act standard)).

64. Cargill, 107 S. Ct. at 498 (Stevens, J. dissenting). 
trust laws, especially in the Clayton Act, is far froin over. The Chicago School continues to claim that the legislative history supports its assertion that allocative efficiency is the primary, if not the exclusive, goal of antitrust. ${ }^{65}$ Critics of the Chicago School concede that efficiencies play a part in the regime Congress desired to establish, but inaintain that the regime actually reflects an interplay of various values, different coinbinations of which can rise to predominance depending on the industry considered. ${ }^{66}$

A survey of the legislative history and its modern analysis suggests that the latter view is more true than the former. As commentators have observed, divining congressional goals to a certainty is impossible, although the endeavor provides valuable lessons for the developinent of operational pohicies. ${ }^{67}$ The Clayton Act and its amendments are political responses to specific societal trends; ${ }^{68}$ the legislative history reflects the influence of the poitical constituencies having interests in those trends. ${ }^{69}$ Nonetheless, the regime that was established, and the congressional efforts to preserve it through amendment, do show that Congress valued certain kinds of firm behavior and disapproved of others. The legislative history makes it clear that the Clayton Act aims to prevent injuries specific to its purpose and design, injuries different from those proscribed by other antitrust laws.

Cominentators on all sides of the Clayton Act debate divide their analysis into several categories of concerns reflected in the legislative history. Among these categories, however, hittle research focuses on the congressional concern for the ways a merger might injure a rival of the merged firm. Because standing analysis requires a court to measure the injury alleged by an antitrust plamtiff against the type of mjuries Congress intended to prevent, the legislative history must be searched for references to the ways Congress saw merger as injurious to competitors

65. See Bork, Legislative Intent and the Policy of the Sherman Act, 9 J.L. \& EcoN. 7, 11-13 (1966) (legislative history reveals a dominant concern for efficiency); Easterbrook, supra note 44, at 3-4; see also Baxter, Separation of Powers, Prosecutorial Discretion, and the "Common Law" Nature of Antitrust Law, 60 TEX. L. REv. 661, 692-94 (1982) (Baxter was then the Deputy Attorney General in charge of the Antitrust Division).

66. See, e.g., Hovenkamp, Antitrust Policy After Chicago, 84 Mich. L. REv. 213, 283-84 (1985) (conceding that the economic lessons of the Chicago School regarding efficiencies are a valuable contribution, but arguing that other values must continue to play a part in antitrust policy).

67. See Fisher \& Lande, supra note 10, at 1589 n.36.

68. Professor Bok's thorough analysis of the Celler-Kefauver Amendments' history concludes that they were passed to address five fundamental concerns: (1) concentration of industry had reached exceedingly high levels in the U.S.; (2) concentration was continuing to increase; (3) mergers played a major role in this trend; (4) the trend involved large firms swallowing up small firms; and (5) the original version of $\S 7$ was defective because it allowed for acquisition through the purchase of assets. Bok, Section 7 of the Clayton Act and the Merging of Law and Economics, 74 HARV. L. REv. 226, 234-35 (1960).

69. Hovenkamp, supra note 66 , at 250 . 
as well as competition. In this section, I will identify the notions of competitor injury contained in each of the traditional categories of legislative concern.

\section{The Foundations of Congressional Concern}

The analytical framework for analyzing the legislative history of the Clayton Act was first identified by the Supreme Court, after Congress rectified the Act's original infirmities through the Celler-Kefauver Amendments. ${ }^{70}$ In Brown Shoe Co. v. United States, the Court stated: "The dominant theme pervading congressional consideration of the 1950 amendinents was a fear of what was considered to be a rising tide of economic concentration in the American econonny." 71 The Court stressed that Congress found the process of concentration to be "a dynamic force" and therefore sought to prevent it im its incipiency, "before it gathered momentum."72 The Court also identified "other considerations" underlying the Amendments, including the desirability of retaining local control over mdustry and protecting sinall businesses, as well as a more general congressional desire to protect the social and economic values promoted by coinpetition and threatened by concentration. ${ }^{73}$

Congress demonstrably feared the impact that trends toward concentration would have on local control, small businesses, individual economic determination and the pohtical system. Congress viewed econounic concentration as a harmful process. Consequently, the record describes harms that arise as markets concentrate as well as harms that occur after markets are controlled by only a few players. Harms attributable to markets that are already concentrated, like monopoly pricing and profits, oligopolistic control, and collusion, were already prohibited by the Sherman Act. Injuries that occur only through the process of concentration, therefore, make up a distinct set of concerns that section 7 was designed to address.

Speeches recorded in the legislative history of the Celler-Kefauver Amendments share a common organization. Most begin with brief invocations of the evils of concentrated markets. Then, inore thorough findings are offered as to the harms that arise as markets become concentrated. Close reading of the legislative history of the CellerKefauver Amendments reveals the congressional concern that coinpetitors could be injured by lessened competition and by the unfairly advantageous position a firm could gain by merging with one of its rivals.

\footnotetext{
70. See supra notes $59-63$ and accompanying text.

71. 370 U.S. 294,315 (1962).

72. Id. at $317-18$.

73. Id. at 315-16.
} 


\section{The Harms of Concentrated Markets}

The economic lessons of the Sherman Act provided a background for the design of the Clayton Act. There was little disagreement within Congress that concentrated markets are contrary to public policy $m$ that they produce unduly high prices and unjustified scarcity. ${ }^{74}$ Concentrated markets foster oligopolistic market structures im which collusion becomes administrable, and the few existing firms operate froin a position of power even though none possesses a pure monopoly. ${ }^{75}$ Reflecting the lessons of the Great Depression, the Clayton Act debates contain repeated assertions that, in concentrated markets, firms facing declining demand have the ability to reduce production while maintaming price to the detriment of the "general welfare."

Discussions of the socio-political impacts of concentrated markets often accompanied these economic descriptions. ${ }^{77}$ The Brown Shoe Court noted congressional warnings that concentration of economic and political power could lead to popular upheaval and collectivism-either fascist or communist. ${ }^{78}$ The record also reflects concern that economic concentration leads to geographic concentration of big busmess, big uinons and big government in the nation's commercial hubs. Congress preferred distributing economic power among the local communities corporate decisions most directly effect. ${ }^{79}$

Regulation to protect these imterests is not unique to the Clayton Act. Illegal behavior in concentrated markets could already be reached through the law of attempt and the monopolization provisions of the Sherman Act. In contrast, the Clayton Act also addresses harms that Congress viewed as arising from the process of economic concentration. Accordingly, injuries Congress identified with the process of concentration should define the standard used to test claims of antitrust injury due to a merger of the plaintiff's rivals.

74. See, e.g., 95 CoNG. REc. 11,493 (1949) (statement of Rep. Yates) (when three or four large firms control a market, they operate in a "live-and-let-live" atmosphere). These assertions reflect the traditional definition of market power-the power to raise prices and reduce output due to security that competitors will not fill the void.

75. See, e.g., id. at 11,493-95 (statement of Rep. Yates). These assertions reflect the lessons of Sherman Act $\S 1$, prohibiting agreements in restraint of trade. See 15 U.S.C. $\S 1$ (1982).

76. 95 CONG. REC. 11,493 (1949); see also id. at 11,495 (statement of Rep. Bryson). The Celler-Kefauver Amendments followed periods of post-depression and post-war dechine.

77. See, e.g., Bok, supra note 68, at 234-35 (describing congressional discussions during Clayton Act debates and summarizing socioeconomic perspectives embodied therein).

78. Brown Shoe Co. v. United States, 370 U.S. 294, 333 n.60 (1962); see also 96 CoNG. Rec. 16,452 (1950) (statement of Sen. Kefauver); id. at 16,507 (statement of Sen. O'Connor); 95 CoNG. REC. 11,494 (1949) (statement of Rep. Yates) (all three cite the predictions of Marx that the excesses of unrestrained capitalism will usher in the socialist era).

79. See, e.g., 96 Cong. Rec. 16,452 (1950) (statement of Sen. Kefauver); 95 Cong. Rec. 11,495 (1949) (statement of Rep. Bryson). 


\section{The Harms of Concentration Process}

Discussions in the legislative history regarding the evils of the process of concentration suggest a model of economics that focuses on the communicative nature of the basic exchange of goods and services. Society distributes resources as the spoils of competition to the producers of items most valued by consumers. The spoils of innovation or comparative quality then fuel the growth of successful firms, and this growth motivates others to duplicate or to improve upon the successful firm's offering. ${ }^{80}$ Discussions of each of the legislative concerns identified by the Brown Shoe Court ${ }^{81}$ suggest that the Clayton Act was designed to preserve channels of consumer communication. In each category, the record evidences a concern that by obstructing transmission of consumer preference for one competitive strategy over another, a merger might harm both competitors and competition. Thus, the Clayton Act was designed to prevent the obfuscation of consuiner preferences as well as the collusion caused by a merger of rivals in a concentrated market. Accordingly, discussions in the legislative history that reflect a desire to protect (1) competitors and (2) the commumication of consumer preferences illustrate the parameters of antitrust injuries attendant to a merger of rivals.

\section{a. Protection of Local Control}

Senator Kefauver stated that the protection of local control was an attempt to keep economic power in the hands of the consumers. ${ }^{82}$ Consumer power is expressed through purchasing decisions and to a lesser degree through customer complaints or comphiments. Congress' protection of local control suggests a finding that concentration can impede the communication of economic information between consunier and producer. ${ }^{83}$ While conipetition was found to keep prices low and quality high, the effectiveness of competition is dependent upon the ability of consumers to commumicate preferences to which producers must

80. For a more thorough discussion of the commumicative model of economics, particularly as regards its vision of dynamic efficiency, see infra notes $127-30$ and accompanying text.

81. 370 U.S. at 315-16; see supra notes 71-73 and accompanying text.

82. 96 CONG. REC. 16,452 (1950).

83. 95 CoNG. REc. 11,495 (1949) (statement of Sen. Bryson). Senator Bryson's lengthy statement regarding the ways in which the amendments were to preserve local control reveals the values Congress meant to protect thereby: (1) familiarity between management and the community; (2) local investment and expenditure of revenues; and (3) strong social and civil ties which bind busimess and the community. See also id. at 11,496 (statement of Rep. Boggs, discussed infra note 94 and accompanying text). These values continue to effect policymaking in antimerger law and are a major impetus for the recent enforcement efforts of the National Association of State Attorneys General. See State Guidelines, supra note 10; see also NAAG Adopts Enforcement Guidelines for State Review of Horizontal Mergers, 52 Antitrust \& Trade Reg. Rep. (BNA) 476 (Mar. 12, 1987). 
respond. The record suggests an inverse relationship between concentration and producer responsiveness.

\section{b. Internal Growth}

The preceding description of the congressional model of competition is further supported by statements in the legislative history that internal growth is preferable to inerger. To Congress, the vigorousness of coinpetition depended upon the decisions of firms as well as those of consumers. The Clayton Act was an attempt to preserve a competitor's freedom to inake the decisions necessary to distinguish its offering in terins of organization, price, product function, and quality. ${ }^{84}$ Internal expansion is favored because it is based on an economic vote of confidence by either consuiners or investors. ${ }^{85}$ Increased power by inerger is the antithesis of "Ineritorious competitive development" because it eliminates a point of competitive interchange. ${ }^{86}$ Growth by merger may allow to stand certain weaker decisions of the merging firms, decisions that would have been corrected if exposed to inarket forces. Similarly, competitive forces have greater occasion to correct the direction of growth if that growth is by internal development rather than by acquisition. ${ }^{87}$

84. See, e.g., 96 CoNG. REc. 16,449-50 (1950) (statement of Sen. Kefauver) (importance of maintaining free market structure); 95 CoNG. REC. 11,493 (1949) (statement of Rep. Carrol) (importance of innovation); id. (statement of Rep. Yates) (capital market exposes company's organization to competitive scrutiny); see also Litvack, supra note 7, at 657 (stressing the importance of protecting entrepreneurial innovation and economic decentralization).

85. 95 CoNG. REC. 11,493 (1949) (statement of Rep. Yates) (consumer vote of confidence by trading with a firm verifies propriety of growth by reinvestment of earnings; capital market exposes firm to scrutiny of investment bankers in competitive setting); see also United States v. Philadelphia Nat'l Bank, 374 U.S. 321, 370 (1963) ("surely one premise of an antimerger statute such as $\S 7$ is that corporate growth by internal expansion is socially preferable to growth by acquisition"). The use of interual growth here is not to argue that merger is never preferable; Congress' discussion is merely being applied to identify the values which it sought to pursue. Indeed, the Celler-Kefauver Amendment was designed to allow small firms to merge so they could compete with larger firms. See infra notes 88-100 and accompanying text; see also Fisher \& Lande, supra note 10, at 1660-61 n.262.

86. 96 CONG. REC. 16,452 (1950) (statement of Sen. Kefauver) The Senator's linkage of meritorious growth with statements that free enterprise is based on individualism suggests that earned growth is proper, while purchased growth is not.

87. 95 CoNG. REC. 11,493 (1949) (statement of Rep. Yates). After discussing the competitive forces which come to bear on interual expansion and concluding that such growth does not create either an inherent probability that competition will be reduced or a presumption that its purpose is monopoly, Rep. Yates stated:

The third method of expanding, however, is inherently dangerous to competition. It consists of buying out going concerns. A desire to get rid of inconvenient competitors is one of the most probable motives for this type of expansion. And even where the motive does not exist, elimination of one competitor after another and a consequent weakening of competition is the almost inevitable result. When a concern expands by reinvesting profits or floating security issues, nothing in its action prevents others from trying to expand too. When a conceru expands by acquiring its competitors, its growth and a reduction of the number and strength of competitors are two aspects of the same transaction. Hence we do well to look with suspicion upon the buying out of competitors .... 


\section{c. Protection of Small Business}

Congressional references to the need to protect small businesses can be attributed to the fear generated by a contemporary FTC report that suggested that competition was being eliminated through large firm acquisition of small firms. ${ }^{88}$ This background suggests that the broad protective statements in the record are not without limits-Congress imtended to protect small busmesses only from certain kinds of large firm behavior. In order to preserve small business and entrepreneurs as active and dynamic sources of competitive pressure, ${ }^{89}$ Congress designed the Clayton Act to prevent the development of market structures that enable large firms to deny small firms the freedom to compete on their own terms. Likewise, Congress sought to prevent market structures that would deny consumers the right to choose from the full range of potential products. Congress did not intend, however, to grant firms relief from the natural marketplace forces that pressure a firm to mimic the alternative products or processes of a competitor. As the Supreme Court recently reiterated, in regulating the competitive process, Congress sought to provide relief only from umatural mampulation of those processes. ${ }^{90}$ Given the congressional concern for the communicative

Id. See also id. at 11,501 (statement of Rep. Douglas) (evidence of then-current trend that large corporations were using merger as a device to eliminate competitors). The "sweetness" of an acquisition deal above the reasonable value of the acquired firm's assets may reflect the large firm's perceived returns on ehiminating a point of competitive interchange.

88. See S. Rep. No. 1775, 81st Cong., 2d. Sess. 5 (1950) (quoting Federal Trade Commission, The Merger Movement: A SUmmary Report, at 6-7 (1948)).

89. Broad statements of the value of small business and Congress's desire to protect them can be found throughout the record. See, e.g., 95 CoNG. REC. 11,486 (1949) (statement of Rep. Celler) (discussing small business "of the kind that built up our country, of the kind that made our country great"); id. at 11,489 (statement of Rep. Keating) (desirable to preserve small business as an active and dynamic force); id. at 11,494 (statement of Rep. Yates) (small business is a key feature of free enterprise); 96 CONG. REC. 16,434 (1950) (statement of Sen. O'Connor) (preserve small business as the important competitive factor in the American economy).

Professor Hovenkamp argues that the prevalence of such sweeping statements in the legislative history is due to an aggressive lobbying effort that was waged upon Congress by various groups representing that constituency. Hovenkamp, supra note 66, at 250. Hovenkamp's suggestion that the comments were likely to bc politically motivated audience-pleasers is supported by the fact that Congress did not include absolute protective statements in the statutory language. Nowhere does the Clayton Act state fiatly that where the interests of a large firm conflict with those of a small business, the interests of the small business should be favored.

Though the influence of lobbyists may have colored the record as to the degree of congressional intent to protect small business, thcy may also have served a more disinterested function. Lobbyists have access to information which may be more specialized or more difficult to gather than that which Congress can obtain. Accordingly, it is also likely that where legislators make specific reference to the circumstances in which big businesses can harm small businesses, they are informed by specific information which substantiates the testimony of the record.

90. See Associated Gen. Contractors v. California State Council of Carpenters, 459 U.S. 519, 528 (1983) ("Coercive activity that prevents its victims from making free choices between market alternatives is inherently destructive of competitivc conditions and may be condemned [through the Sherman Actl even without proof of its actual market effect."). 
nature of competition, statements in the record addressing the protection of sinall business offer a fertile source for description of the ways mergers can injure coinpetitors.

Representative Celler described the way concentrated inarkets put large businesses in a position to constrain smaller businesses and noted that, due to such positioning, sinall businesses were either disappearing or being made dependent upon "inonster concentration." that "[b]igness does not inean efficiency, a better product or lower prices." "Bigness" can yield cost advantages that are not necessarily efficient in terms of Celler's view of efficiency. For example, if a firm has power, it inay coinpel supphiers to take the price that it sets. Similarly, by spending a small percentage of its sales revenues on advertising, a firm can exploit volume discounts to force sinall competitors to overextend or be silenced. ${ }^{93}$ Celler also observed, "Great wealth and credit are frequently matters of favor or accident or sheer power," big firm inay constrain a sinaller one simply through the influence it maintains in the inarket for credit-a inarket in which rivals compete for an input that inay be essential to a firm's ability to retool or ninovate in response to coinpetitive pressure.

In his lengthy discussion of small firms and local control, Representative Boggs identified two of the reasons sinall firms had been selling out by describing situations he perceived the Amendinents would prevent: (1) large firms implementing constraints on sinall firms' abilities to "obtain critical inaterials, supphies and parts;" and (2) large firms coercing sell-outs through "threats, intimidations and unfair practices on the part of large companies." 95

In responding to the alleged inability of the amended Act to reach certain types of concentration that occur in declining industries or during periods of economic recession, Senator Kefauver described ways in which a monopolist might constrain a smaller firm. Although contrary to the spirit of the antitrust laws, soine anticompetitive behavior might not be prohibited unless the amendınents were enacted:

Unfortunately, if those big corporations are led to think that perhaps by depriving sinall business of contracts and subcontractors, or by depriving

91. 95 CONG. REC. 11,486 (1949).

92. Id.

93. Although advertising is subject to economies of scale that, arguably, large firms should be allowed to exploit, the abuse of such a position evidently troubled Representative Celler. The tone of his statement suggests that exploitation of economies of scale for purposes of predation would be injurious conduct the Clayton Act was designed to prevent. Although quantitative assessment of predatory behaviors can be problematic, in the hypothetical posed, predatory intent might be inferred from rapidly declining marginal utility (additional sales/last dollar spent) at the level of advertising expenditure budgeted by the large firm.

94. 95 CONG. REC. 11,486 (1949).

95. Id. at 11,496 . 
them of necessary raw materials, they are going to be able to force them to sell their outfits, then the temptation would be present to do so; whereas, if the smaller firms had the protection of this bill, it seems to me the temptation would not be so great for the big corporation to bring about conditions under which the small fellow would be forced to sell to him. ${ }^{96}$

For Senator Kefauver's hypothetical corporation not to be in violation of section 1 of the Sherman Act, ${ }^{97}$ the Senator must have envisioned it creating anticompetitive "conditions" through means other than conspiratorial boycott agreements. ${ }^{98}$ It is unclear, however, how the hypothetical corporation could avoid hability for these acts under Sherman Act section $2,{ }^{99}$ which forbids such conduct by a firm holding monopoly power. It is clear that if the corporation were merely large enough to influence market conditions but lacked monopoly power, its conduct would not meet the "dangerous probability of success" standard applied to identify atteinpts to monopolize under the Sherman Act. ${ }^{100}$ Accordmgly, such behavior might escape the regulatory scope of the Sherman Act. It is credible, therefore, that the Clayton Act amendments were fashioned to adequately protect sinall firms from the anticompetitive pressures envisioned by Senator Kefauver to the extent that such pressures could not be controlled by the Sherman Act.

\section{d. Incipiency Concerns}

Congress desigued the ainendments to prevent the development of market structures that would limit coinpetitive options in the ways described by Representatives Celler and Boggs and Senator Kefauver. ${ }^{101}$ Congress's concern for the harms inherent in the process of concentration is reflected in its desire to stop development of such market structures in their "incipiency," "well before [the structures have] attained such effects as would justify a Sherman Act proceeding." 102 As the Brown Shoe Court concluded, Congress intended to stop the "rising tide

96. 96 CONG. REC. 16,448 (1950).

97. 15 U.S.C. $\$ 1$ (1982).

98. Boycott agreements and similar conspiratorial coercion can be reached through the Sherman Act. See supra note 90.

99. 15 U.S.C. $\$ 2$ (1982).

100. See American Tobacco Co. v. United States, 328 U.S. 781, 785 (1946) (an attempt to monopolize is "the employment of methods, means and practices which would, if successful, accomplish monopolization, and which, though falling short, nevertheless approaches so close as to create a dangerous probability of it").

101. See supra note 89 and accompanying text.

102. S. Rep. No. 1775, 81 st Cong., 2d Sess. 45 (1950); 96 CoNG. REc. 16,453 (1950) (statement of Sen. Kefauver); see also Cargill, 107 S. Ct. at 497 n.3 (Stevens, J., dissenting) ("'Congress saw the process of concentration in American business as a dynamic force; it sought to assure . . . the courts the power to brake this force at its outset and before it gathered momentum.") (quoting Brown Slioe Co. v. United States, 370 U.S. 294, 317-18 (1962)); State Guidelines, supra note 10, at S-3 (finding 
of economic concentration." 103 The theory under which the legislators were operating was derived from the 1948 FTC report on concentration. The report concluded that the anticompetitive concentration levels surveyed had arisen through a process of accretion-the elimmation of one competitor after another through merger. ${ }^{104}$ Professor Schwartz has since noted trends demonstrating that congressional fears of such accretion were well founded. ${ }^{105}$ Mergers can trigger similar mergers, as they have in the deregulated airline imdustry, for example. ${ }^{106}$

During hearings on the Clayton Act, lobbyists representimg the interests of big business argued that the pursuit of efficiency justified allowing greater concentration before triggering regulatory intervention. After questioning the lobbyists, however, Representative Boggs concluded that the alleged realization of efficiencies had no foundation in the concentration trends of the 1940 's. ${ }^{107}$ None of the representatives of merger-active corporations could identify efficiencies that had accrued through any of their recent mergers. Boggs concluded that these firms were motivated by a desire to monopolize the market. Rather than using efficiency generated cost savings to fund new developments or lower prices, firms were stockpiling hquid assets until they could acquire competing firuns. The loss of competition that occurs as each additional small business is devoured runs contrary to congressional concerns discussed above. In rejecting the arguments of business lobbyists, Congress apparently concluded that the harin to competition that occurs as a market becomes concentrated is substantial enough to warrant judicial intervention based only on the probability that harm would occur in the future. ${ }^{108}$

Congress did not find all concentration sufficiently anticompetitive to warrant intervention, however. In response to court decisions that had interpreted the Clayton Act to prohibit the merger of two small, local firuns, the Celler-Kefauver Amendments discarded a provision

Congress intended to prohibit mergers even when result would be less than actual attainment or exercise of market power).

103. 370 U.S. at 317-18; see also 95 CONG. REc. 11,501 (1949) (statement of Rep. Douglas) ("In appraising the overall effect of mergers on economic concentration, it must be kept in mind that mergers become cumulative over a period of time. In other words, each year's mergers are superimposed upon a structure of economic concentration which has been built up over many past years.").

104. See, e.g., S. Rep. No. 1775, 81st Cong., 2d Sess. 4-5 (1950); 95 Cong. Rec. 11,493 (1949) (statement of Rep. Yates); id. at 11,501 (statement of Rep. Douglas).

105. See Schwartz, supra note 59, at 601 .

106. On the airline industry, see Kahn, Deregulatory Schizophrenia, 75 CALIF. L. REv. 1059 (1987); see also infra note 195 and accompanying text.

107. 95 CONG. REC. 11,496 (1949).

108. See also Fisher \& Lande, supra note 10, at $1591 \mathrm{n} .49$ (discussing congressional concerns for stopping concentration in its early stages). 
courts had misinterpreted. ${ }^{109}$ The legislative history purposefully identified the phrase "substantially to lessen competition" as implying a change im concentration higher than would arise out of a merger of two non-dominant firms."10 Congress found that "mergers which enable small companies to compete more effectively with giant corporations generally do not reduce competition, but rather intensify it." 111 Representative Boggs concluded that the Celler-Kefauver Amendments had preserved efficiency im the language of the Act by allowing small businesses to merge towards economies of scale. ${ }^{112}$ This findimg was reiterated in 1976 when Congress excluded sinall firm mergers from the reporting procedures of the Hart-Scott-Rodino Amendments. ${ }^{113}$

\section{e. Efficiency Concerns}

Senator Boggs' statement foreshadowed the major enforcement policy debate of the 1980's: To what extent should efficiency considerations play a part in merger analysis? The main lesson that the debate offers this discussion is that the congressional concept of efficiency, if there imdeed was one, necessarily reflects the communicative model of the marketplace Congress was applying.

In an early analysis of the legislative history, Professor Bok observed that the record mcluded very few references to economic efficiency, and instead reflected a model of competition in a social and political context. ${ }^{14}$ Congress's failure to specify the relative importance of efficiencies beyond small business economies of scale has frustrated the debate. Chicago School commentators have analyzed the legislative history and concluded that the Clayton Act protects allocative efficiency. ${ }^{115}$ Other commentators conclude that such a view is unsupported in the expressed intent of Congress, the content of the statutes, and the interpretations of courts. ${ }^{116}$

In a thorough analysis of the efficiency debate, Fisher and Lande argue that, in drafting the Clayton Act, Congress intended to prevent unfair wealth transfers from consumers to producers with market

109. S. Rep. No. 1775, 81st Cong., 2d Sess. 4-5 (1950).

110. 95 CONG. REc. 11,487-88 (1949) (statement of Rep. Celler); see also 96 CoNG. REC. 16,435 (1950) (statement of Sen. O'Connor) ("Any action by the Federal Trade Commission designed to halt mergers of an inconsequential nature would not be in accordance with the language of the bill and would not be upheld by the courts.").

111. 96 CONG. REC. 16,436 (1950) (statement of Sen. O'Connor).

112. 95 CONG. REC. 11,496 (1949).

113. See Hart-Scott-Rodino Antitrust 1mprovements Act of 1976, Pub. L. 94-435, tit. II, § 201, 90 Stat. 1390 (1976) (codified at 15 U.S.C. \$ 18a (1976), adding section 7A to the Clayton Act).

114. See Bok, supra note 77, at 236-37.

115. See generally R. BORK, The ANTITRUst PaRadox: A POLICY at War WITh ITSElF (1978).

116. See Harris \& Jorde, supra note 5 , at 466 . 
power. ${ }^{117}$ Fisher and Lande assert that Congress intended to achieve its distributive goals with a minimum efficiency loss, yet failed to realize that these two goals can sometimes conflict. ${ }^{118}$ Because Congress had not resolved the trade-off between market power and econormic efficiency, the Supreine Court rejected an efficiencies balancing test as too complex for litigation and found the congressional intent to preserve unconcentrated markets to be overriding. ${ }^{119}$ Fisher and Lande also point out that apphed economics caimot conclusively demonstrate that inergers serve the pursuit of efficiency nor can it accurately predict which mergers will yield efficiency and which will not. They conclude, therefore, that apphied economics affirms the Court's conclusion that the market power/ efficiencies trade-off cannot be practically implemented. ${ }^{120}$ Notwithstanding the weaknesses in efficiency-based policy, efficiencies seem to be winning the day in government enforcement decisions. ${ }^{121}$

Although scholars on both sides of the debate attempt to find answers to the efficiency debate in the legislative history, the Congressional Record does not exhibit a dominant concern for efficiencies. ${ }^{122}$

117. See Fisher \& Lande, supra note 10 , at $1585-87$.

118. Id. at 1585.

119. Id. at 1585-86.

120. Fisher and Lande conclude that simple guidelines can effectively account for mergers that have important efficiency effects wlile preventing those mergers likely to have anticompetitive effects. Id. at 1586-87. In 1984, Professors Harris and Jorde attempted to design guidelines more suited to these goals. See Harris \& Jorde, supra note 10, at 469 (proposing an alternative method of market definition incorporating efficiency concerns and other values of antitrust policy).

121. The Justice Department lias subtly modified the 1982 guidelines and has stated that it will consider all claims of efficiencies. See United States Dep't of Justice, supra note 5. This new pohicy has substantially broadened merging firms' arguments in defense of the transaction. See Miller, supra note 7, at 661-62. Fears that the discretion embodied in the 1982 guidelines would lead to slackened prosecution seem to have been well founded. Compare Scliwartz, supra note 59, at 579 \& n. 18 (expressing concern for potential drop in antitrust prosecutions) with Rodino, supra note 8 and accompanying text (compiling merger statistics since 1979).

Evidentiary issues argued to the Tenth Circuit in Cargill suggest the role efficiencies play in contemporary government merger analysis. The appellant argned that the district court lad erred in refusing to consider various structural factors it presented to rebut the statistical presunption of illegality. Monfort of Colorado, Inc. v. Cargill, Inc., 761 F.2d 570, 580 (1985). The firm argued that the government approved the merger based on its Hart-Scott-Rodino Report and that the Report included evidence of anticipated efficiencies the 1984 guidelines rccoguized as relevant. II. The government will now typically consider efficiency evidence to slow that the merger was "not likely to substantially lesson coinpetition" where statistical evidence gives rise to a "siguificant competitive concern." 1984 Merger Guidelines, 49 Fed. Reg. 26,831 (1984). The circuit court held the evidence presented bore questionable relevance to the reliability of the statistical or historical information upon which the lower court had based its decision. 761 F.2d at 580. The Tenth Circuit opinion suggests, therefore, that factors the enforcennent agencies find relevant to salvaging an otlerwise illegal merger may not be relevant under traditional merger law. See id. (citing cases) (The Supreme Court did not review this portion of the Tentl Circuit opinion). The case illustrates the possibility that, by increasing the importance of efficiencies in merger analysis, the governinent may approve mergers which courts would find prohibited by the Clayton Act. Private enforcement of the merger statute thus serves an essential monitoring function.

122. See Hovenkanp, supra note 66 , at 255 . Hovenkamp argues further that the new Chicago 
More recent treatments of the subject suggest a concept of distribution embodied in the legislative history, a concept upon which this Comment draws in describing a model in which consumer transactions are of primary importance because of the information they communicate.

Professors Harris and Jorde suggest that, rather than focusing on allocative efficiencies, the legislative history illustrates two main goals: (1) fairness in economic distribution, and (2) procedural fairness-fairness in the process of exchange, regardless of the outcome. ${ }^{123}$ The procedural goal ensures competitive markets for the benefit of consumers and entrepreneurs. ${ }^{124}$ Both benefit from the commumicative nature of the transaction; consumers transmit approval or disapproval and entrepreneurs receive feedback on their imiovations.

A growing consensus holds that Congress's predominant concern was to insure fair and justifiable wealth transfers from consumers to producers. ${ }^{125}$ Representative Rodmo, Chairman of the House Committee on the Judiciary, echoed this view:

Congress has viewed antitrust as a primary tool to maintain an overall balance and fairness in our economic system, one that ensures confidence of imvestors, managers, and the public at large in our free enterprise system. An entrepreneurial system that enjoys the full confidence of the American people will, in the long term, be our best guarantee of innovative and efficient market performance. ${ }^{126}$

Predatory or monopoly prices are "inefficient," therefore, in that they do not transmit appropriate societal valuations of certain products and services. Rather than setting prices in response to market forces, firms with market power set prices to effect those forces. Furthermore, their price strategies take wealth from consumers that would otherwise be used to communicate valuations to other sectors of the economy, sectors that will then grow at a rate or in a direction skewed from that which consumers given a free choice would direct.

Perhaps because it found efficiencies so difficult to predict or to identify, ${ }^{127}$ Congress favored internal growth, a process that minimized the

School response is simply to ignore legislative history if it comes in conflict with their neoclassical efficiency price theory model.

123. See Harris \& Jorde, supra note 5 , at $466-67$.

124. Id. at 496.

125. Id.; see aiso Fisher \& Lande, supra note 10, at 1590 \& n.43; Foer, The Political-Economic Nature of Antitrust, 27 ST. Louis U.L.J. 331, 334 (1983) (freeing the marketplace through antitrust allows consumers to utilize limited resources efficiently).

126. See Rodino, supra note 8 , at 2.

127. See supra notes 107-08 and accompanying text (discussing survey by Rep. Boggs regarding post-merger inability to identify resulting efficiencies); supra note 91 and accompanying text (discussing statement of Rep. Celler: "Bigness does not mean efficiency, lower price or a better product."); see also notes 117-20 (discussing conclusions of Fisher and Lande that applied economics is unable to accurately predict efficiency yields of mergers).

A recent article by Adams and Brock casts doubt upon the efficiency yields of current merger 
societal costs of allowing firms to grow to efficiency-yielding sizes. In so doing, Congress implicitly determined that efficiencies sliould be confirmed by internal growtl. As an efficient firm grows, it slould be able to reduce price. In capital intensive industries, for example, a 1narketing innovator wlio chooses to add capacity to his operation may be forced to add large production facilities. But if the innovator believes tliat adding capacity will allow him to sell at a lower price, the innovator may accept the risks of inajor investinent. The decisions of consuiners to purcliase his lower-priced goods would then confirm or disapprove his choice.

Congress did identify two areas, however, in which requiring efficiencies to be pursued through internal growth could lead to social waste. Botl failing companies and sinall companies in markets where scale econonies have been demonstrated fall outside the antimerger provision. Growtli does not require the wasteful duplication of capacity-enliancing equipnient. A firm desiring to mimic the efficiency-yielding growth of a larger firm inay elect to purchase a firm that is failing due to the price pressure caused by the efficient firm's innovation. Similarly, a larger firm's ability to sell profitably at a lower price could confirm that econoimies of scale do exist in the industry, economies that were unpredictable before they were realized. ${ }^{128}$ The congressional design allows small compamies in such an environment to merge toward efficiency, subject to the current concentration level in the market. ${ }^{129}$

activity. They contend that "merger mania" itself has opportunity costs-distracting management and draining revenue that could be spent on productivity enhancement. Their research confirms Rep. Boggs' conclusion that firms stockpile cash in order to make acquisitions. In 1984, firms spent $21 / 2$ times as much on merger and acquisition as on innovation. Adams \& Brock, The "New Learning" and the Euthanasia of Antitrust, 74 CALIF. L. REv. 1516, 1551 \& n.165 (1986).

128. See supra note 33 and accompanying text. This Comment cannot attempt to enter the debate regarding the potential in this area for development of an efficiency defense. While price differences between an efficiency innovator and smaller firms may be evidence that economies could be gained by merger, other factors could distinguish the firms so that the post-merger firm would yield different efficiencies, such as management style.

129. This discussion reflects some of the differences between dynamic efficiency and allocative efficiency. The congressional model is best reflected by the theory of dynamic efficiency, a theory which focuses on the process of innovation and the ways in which competition effects it. See Foer, supra note 125, at 334-35 (describing dynamic efficiency); Scherer, Antitrust, Efficiency, and Progress, 62 N.Y.U. L. REV. 998 (1987). In contrast, the Chicago School argues antitrust laws should recognize allocative efficiency as supreme. Based on faith in the corrective powers of the market, and on a belief that Congress did not intend to inhibit overall efficiency by requiring duplication of efforts by many small firms, Chicago School enforcement policies attempt to avoid suppressing any such efficiencies. However, the legislative history of the Clayton Act reveals that Congress accounted for efficiencies, but concluded that such efficiencies are assured only when small businesses merge to gain economies of scale which allow them to compete with larger firms. Efficiencies thus fit into enforcement policy at different points. To the Chicago School, merger toward productive efficiency is itself efficient in a broader sense because it eliminates the waste that can be associated with duplicative efforts toward internal growth. See Scherer, supra, (graphing economic concerns of various perspectives).

The Chicago School emphasizes the chilling effect antitrust enforcement has on efficiency 


\section{Conclusion: The Congressional Model}

The legislative history of section 7 of the Clayton Act reveals a congressional concern for the communicative nature of the economic system. My discussion in this subsection has shown that the concern is apparent in each of the categories of goals traditionally identified in the legislative history. Congress believed that society and technology would progress if consuiner desires, communicated by choices between competing products, allocate economic resources. Congress valued the process that contributes to those choices. A breadth of alternatives serves to educate the consuiner. Production alternatives guarantee breadth as producers struggle to distinguish their products from those of coinpetitors. Product and process innovation are thus fueled by the competitive pressure of clioice in the inarketplace. Congress sought to insure the higliest social utility in the ongoing distribution of economic resources by protecting the signals transmitted by exchange and preserving the choices of consuiners and producers. ${ }^{130}$

\section{Standards for Injury}

Because it deınonstrates that Congress valued the ability to compete freely in the inarket, the legislative history of the Clayton Act offers support to a conipetitor seeking to establish standing under section 7 . The legislators designed the statute to prevent development of inarket structures that allow merging firms to position theinselves so as to deny rivals the freedom to choose aniong an unrestricted range of conipetitive responses. In restricting the responses offered in the market, a merged firm also denies consumers the right to choose from the full range of offerings that would be available had the inerger not redirected developinents in the niarket.

Clearly, a decision to market a new product of such improved quality that it linits the responses available to rivals is not a strategic nove of the type that concerned Congress. Ideally, aggressive conpetition is driven by decisions to increase quality or decrease price. On the other hand, Congress found that inergers obfuscate consumer communication and that, when they place a firm in a position to restrict the competitive

seeking behavior; the congressional model fears approving anticompetitive behavior under the label of efficiency. See supra note 127.

130. Under the theory of dynamic efficiency, an "efficient" economic system is one that maximizes the rate of innovation achieved in expending energy through commercial transaction. Some theorists have taken up the task of identifying market structures whieh best suit that goal. They challenge the classic Schumpeterian conclusion that oligopolies provide the best balance of innovation-inspiring competitive pressure and reward-producing ability to exploit the resulting innovative products. Modern theorists have demonstrated that the unique characteristics of different industries individualize optimal structure. See, e.g., Foer, supra note 125, at 336-37; see also infra notes 191-94 and accompanying text. 
choices of its rivals without changing the nature of its own offering, mergers decrease competitive progress without producing countervailing benefits to society. A merger that demes rival firms the freedom to make coinpetitive choices injures those rivals in a manner Congress sought to prevent. Accordingly, a plaintiff who can show such injury should have standing to raise a claim under section 7 .

Because both the substantive prohibition of section 7 and the injunctive remedy of section 16 apply prospectively to injurious behavior and anticompetitive market structures, a standard of injury under the Clayton Act must test the likelihood that the challenged merger will harm the plaintiff in the manner it alleges. Although the Cargill Court failed to discuss probability of injury, ${ }^{131}$ other courts have required that a competitor seeking rehef under section 7 show a sufficient likelihood of antitrust injury. ${ }^{132}$ A survey of the mjury requirements applied by these courts serves as a ginde to defining a workable standard for testing injuries alleged in merger hitigation.

In Brunswick, the seminal case on antitrust injury, the Supreme Court reviewed a post-merger challenge brought under section 7 by a coinpetitor seeking section 4 treble dainages. Addressing the difficulty of awarding dainages under section 7, the Court noted, "competitors may be able to prove antitrust imjury before they actually are driven from the inarket and competition is thereby lessened."133 In Arthur $S$. Langenderfer, Inc. v. S.E. Johnson Co., ${ }^{134}$ the Sixth Circuit construed Brunswick in an attempt to construct a standard for section 7 injury and concluded, "Brunswick requires that [plaintiff's] imjury result either from a lesseming of competition due to the acquisitions or from 'anticompetitive acts inade possible' by the acquisitions." ${ }^{135}$ The anticompetitive acts

131. In Cargill, the plaintiff apparently failed to link the changing structure of its market with the development of anticompetitive market structures which Congress intended section 7 address. The Cargill Court was not required to move on to this second issue and address the hikelihood of injury sufficient to warrant competitor standing.

132. In Cargill, the Supreme Court approved the holdings of several appellate courts requiring a plaintiff to show antitrust injury. $107 \mathrm{~S}$. Ct. at 490 n.7. The section 7 case cited by the Court, Christian Schmidt Brewing Co. v. G. Heileman Brewing, 753 F.2d 1354 (6th Cir.), cert. dismissed, 469 U.S. 1200 (1985), and the precedent upon which it is based, are arguably strong sources for deriving a standard for likelihood of the mjury alleged. See id. at 1356-58 (citing cases).

133. Brunswick Corp. v. Pueblo-O-Mat, Inc., 429 U.S. 477, 489 n.14 (1977).

134. 729 F.2d 1050 (6th Cir.), cert. denied, 469 U.S. 1036 (1984).

135. Id. at 1058 (quoting Brunswick, 429 U.S. at 489). Langenderfer served as precedent in Christian Schmidt. The imminence of injury required under the Langenderfer standard suggests that the standing issues underlying Brunswick's injury requirement override Congress' incipiency concerns regarding the anticompetitive effects of the next in a series of inergers. Responsibility for early prevention of trends toward concentration inay, therefore, be left to government enforcement. Government standing in merger litigation is statutorily conferred. The governinent need not establish a causal relationship between a merger and liarm to coinpetition because, in governinent actions, statistical representations of concentration give rise to presumptions of illegality. See United States v. Pliiladelphia Nat'l Bank, 374 U.S. 321, 362-63 (1963) (statistical concentration evidence 
to which the court referred are the injuries Congress designed the Clayton Act to prevent.

The Langenderfer test is incomplete, however. The standard fails to test the likelihood that injury will result froin the inerger. Congress designed section 7 to prohibit probable injury. The condemnation of mergers the effect of which "may be to substantially lessen coinpetition" implies a standard of "reasonable probability." A inerger is contrary to congressional intent, therefore, if there is a reasonable probability that it will lead to the injurious inarket structures the Langenderfer test identifies.

The Cargill Court suggested that to make the threshold showing required at the standing phase of inerger hitigation, the plaintiff must present a "credible" theory of antitrust injury. ${ }^{137}$ Once the plaintiff establishes a claim of injury, the hitigation would determine whether the plaintiff could meet the customary requirements for injunctive relief. ${ }^{138}$ Combining the qualified Langenderfer test with the injury concerns sec-

gives rise to a rebuttable presumption of illegality); see also infra notes 201-05 and accompanying text.

Notwithstanding the limitations of a causation requirement, private enforcement of section 7 through section 16 actions does serve Congress's incipiency concerns. See Christian Schmidt, 753 F.2d at 1358 ("Section 16 is designed to stop anticompetitive behavior in its incipiency."). Congress designed the Clayton Act to prevent all of the econounic redistributions that follow an illegal merger, many of which may be irreversible once the merger is consummated. See H.R. Rep. No. 1373, 94th Cong. 2d Sess. 5 (1976) (Hart-Scott-Rodino procedure designed to provide scrutiny of merger "before the assets, technology, and management of the merging firms are hopelessly and irreversibly scrambled together, and before competition is substantially and perhaps irremediably lessened, in violation of the Clayton Act"); see also 95 CONG. REC. 11,493 (1949) (statement of Rep. Yates); Kauper, The 1982 Merger Guidelines: Of Collusion, Efficiency, and Failure, 71 CaLIF. L. REv. 497, 509 (1983) (divestiture often neither effective nor efficient).

136. 96 CoNG. REc. 16,453 (1950) (response of Sen. Kefauver to Minority Report of Sen. Donnel on the Celler-Kefauver Amendment); S. Rep. No. 1775, 81st Cong., 2d Sess. 6 (1950), reprinted in 1950 U.S. CODE CONG. \& ADMIN. NEwS 4293, 4298.

Congress believed a reasonable probability standard was necessary to the Act's purposc of preventing concentration in its incipiency. In this way, Senator Kefauver distinguished the Clayton Act's standard of certainty from that of the Sherman Act. He also rejected the minority's criticism that substantial "possibilities" would be enough to cause liability under the Act. Id.; see also Brown Shoe Co. v. United States, 370 U.S. 294, 323 (1962) (Congress's concern in amending the Clayton Act was for probabilities, not certainties; however, clear-cut menaces, not ephemeral possibilities); supra notes 101-08 and aceompanying text.

137. Cargill, 107 S. Ct. at 494; see also Monfort of Colorado, Inc. v. Cargill, Inc., 761 F.2d 570, 573 (10th Cir. 1985) (showing of injury necessary at threshold stage is lower than that for remedy under § 4) (citing Board of Regents v. NCAA, 707 F.2d 1147, 1151 (10th Cir. 1983) aff'd., 486 U.S. 85 (1984)).

138. The Christian Schmidt court noted that after probabilities establish standing, "plaintiffs must nonetheless make a sufficient showing of potential or threatened antitrust injury to meet the customary requirements for a grant of preliminary injunctive relief." 753 F.2d at 1358; see also Clayton Act $\S 16,15$ U.S.C. $\S 26$ (1982) ("Any person . . . shall be entitled to sue for and have injunctive relief, ... . against threatened loss or damage by a violation of the antitrust laws . . . under the same conditions and principles as injunctive relief . . . is granted by courts of equity . . .."). 
tion 7 addresses, the following standard identifies coinpetitors who have standing to enjoin a merger of their rivals:

\section{Proposed Standard of Injury}

To have standing to seek injunction of a merger, a coinpetitor inust advance a credible theory that:

(1) there is a reasonable probability that the merger puts the merged firm in a position to restrict the coinpetitive choices available to its competitors without changing the quality or price of its own products, or

(2) there is a reasonable probability that the merger will give rise to market structures that could allow the merged firm to exploit such an anticompetitive position.

The standard I propose is consistent with the incipiency concerns of Congress and yet, by concentrating on a plaintiff's coinpetitive choices rather than long term losses, the standard allows for inore immediate proofs. As Cargill shows, attempts to prove actual economic losses are either too speculative or easily countered with applied economics. ${ }^{139}$ These proof problens thwart the congressional desire to create a standard that permits prospective protection of market structure and that may be inore readily satisfied than that of the Sherman Act.

The congressional intent to protect the natural developinent of inarket structure, developinent confirmed by consumer choice, supports the proposed standard. The restriction of a coinpetitor's strategic choices may irreparably inutate the structure of a inarket by distorting transactional consunier communication. If not acconipanied by price reductions or quality enhancenient, the choice-restrictive moves of a inerged firm are socially harmful - they deny consumers the right to choose and thereby to determine a inajor step in the development of the inarket. The limitation on the defendant's immediate freedoin to choose inerger is justified by Congress's preference for ineritorious internal developnient over growth by acquisition.

II

\section{STRATEgIC BEHAVIOR ANALYSIS}

When a firm responds to the pressures of the niarketplace, it is behaving strategically. Strategic behavior analysis enables firms to evaluate the structure of the inarket in which they compete. The analysis identifies the firm's strengths and weaknesses in relation to those of its coinpetitors and to the structure of the nrarket. ${ }^{140}$ Based on this infor-

139. See Cargill, $107 \mathrm{~S}$. Ct. at 494-95 nn.15-17 (discussing difficulties of proving injurious predatory pricing through the facts there in issue).

140. See M. Porter, Competitive Strategy (1980) [hereinafter M. Porter, Strategy]; M. Porter, Competitive Advantage (1985) [hereinafter M. Porter, Advantage]. 
mation, strategic behavior analysis identifies strategic goals and the moves the firm can make to pursue those goals.

Strategic behavior analysis offers two possible apphications in merger litigation. First, it can define market structures in which illegal behavior is likely. Second, it allows competitors to evaluate the impact of a merger of rivals on market structure and to infer whether the postmerger structure will allow the merged firm to limit the competitive choices of remaining rivals.

In this Part, I present the approach and conclusions of one strategic behavior theorist to illustrate the first of these applications-the definition of market structures conducive to illegality. Based on the work of Michael Porter, section A introduces strategic behavior theory as a means of showing how firms behave strategically in a non-merger context. Section B describes the theory's contributions to an understanding of markets and of firm behavior and then apphies the theory to the merger context. I conclude that strategic behavior analysis can identify injurious behaviors in a way that comprehends the complex economic and non-economic motivations behind such behaviors as well as the more quantifiable factors favored by current antitrust law.

\section{A. Strategic Behavior}

Strategic behavior theory assumes that inarket structure affects the range of choices available to a firm and that, once made, the firm's choices can affect the structure of a market. ${ }^{141}$ The goal of coinpetitive strategy is to go beyond responding to market structure by consciously shapimg it to enhance a firm's performance. ${ }^{142}$ Porter suggests that a firm can enhance performance through strategic inoves designed to lessen the intensity of the five competitive forces: (1) threats of entry; (2) rivalry; (3) pressure from substitute goods; (4) bargaining power of buyers; and (5) bargaining power of sellers. ${ }^{143}$ Because these forces are inutually dependent, a move targeting one will affect the other four. ${ }^{144}$ Strategic behavior hiterature describes methods of analysis used to predict the systemic effects of strategic moves. The goal of this analysis is to identify moves that enhance the actor's performance without giving rise to "destabilizing and costly warfare,"145 circumstances similar to those

141. See generally Williamson, Delimiting Antitrust, 76 GEO. L.J. 271, 289-93 (1987) (strategic belavior occurs when firms, individuals, or other sociopolitical entities choose deeision variables in conscious awareness that these influence the opportunity set of other firms, individuals or sociopolitical entities).

142. M. Porter, AdVANTage, supra note 140, at 2.

143. See M. Porter, Strategy, supra note 140 , at 1-33.

144. Id. at 184 .

145. Id. at 91. 
economists refer to as "perfect competition."146 A major component of the analysis is the "competitor profile," 147 data identifying the nature and success of a competitor's strategic changes and his probable response to moves by other firms or to choices in the industry or environment.

From the data and profiles provided by strategic behavior analysis, a firm will attempt to design strategic moves that influence the balance of competitive forces to its own advantage while limitimg the ability of a competitor to retaliate. Retaliation will be lessened if the actor chooses "the best battleground," that market segment or dimension of strategy im which competitors are ill-prepared, unenthusiastic, or uncomfortable about competing. ${ }^{148}$ The origin of their discomfort may be the internal characteristics listed above or it may be the signals sent by the actor. Signals can be simple announcements of commitment or distaste or perhaps more complex behaviors designed to discipline competing firms without major effort or cost. ${ }^{149}$ Whatever the cause, "the best battleground" is one im which a competitor's circnmstances, revealed in the competitor profile, either prevent it from responding to a particular competitive nove, or create a situation in which effective retaliation would also hurt the competitor's own position. ${ }^{150}$

Porter finds an example of strategic behavior in the Swiss watch imdustry, whose firms were effectively put at cross-purposes by the introduction of inexpensive brand name products. Because Swiss watches

146. Id. at 6. Porter's work shows that strategic behavior analysis focuses on many of the same factors traditional economics has taught antitrust courts to consider. The advantage of Porter's approach is that it breaks these considerations into more precise subfactors, fine-tuning analysis of the competitive process. For example, Porter identifies seven types of entry barriers which, by themselves or in combination, can protect market structure: (1) economies of scale; (2) product differentiation; (3) capital requirements; (4) switching costs (costs faced by a purchaser switching to a new supplier); (5) access to distribution channels; (6) cost disadvantages independent of scale; and (7) government policy. Id. at 7-13. Porter also interrelates various structural features with which antitrust theorists are familiar. For example, Porter ideutifies several features which contribute to the intensity of industry rivalry and destabilize market structure: numerous or equally balanced competitors, slow industry growth, high fixed or storage costs, lack of differentiation or switching costs, systems requiring large capacity increments for growth, diverse competitors, high strategic stakes, and high exit barriers (emotional and social as well as financial barriers). Id. at 18-21.

147. Id. at 47-74. The profile includes a competitor's current strategy and capabilities as well as its future goals and assumptions-both profit-related and more broadly based. The methodology recognizes the extent to which values other than profit typically enter a firm's decision making process.

148. Id. at 70 .

149. Id. at 75-87. One signaling behavior Porter discusses is the "cross-parry." As a means of signaling distaste for a competitor's activities in its favored market, a firm may imitiate a price cut in the coinpetitor's favored market, where the actor inaintains a small-share presence. While clearly disciplinary, the cross-parry allows the communicator to threaten full-scale retaliation without actually increasing responsive pressure from competitors, rivalry, and thereby injuring industry structure, in Porter's view. In other words, the cross-parry is a strategic opportunity to bluff. Id. at 84.

150. Id. at 70 . 
were marketed as luxury, precision instruments through jewelry stores, manufacturers were unable to respond to the growth in product demand and the loss of marginal customers that followed Timex's marketing innovation-mass production and wide distribution of inexpensive, practical watches. Entering the new market would undermine the image of prestige and precision associated with Swiss watches. Furthermore, it would expose the manufacturers to a more intense rivalry than that to which they were accustomed. At a minimum, the mixed motives of Swiss firms delayed their retaliation, giving Timex time to establish a beachhead and permanently restructure the industry. ${ }^{151}$

Professor Hovenkamp describes strategic behavior as conduct a firm designs to reduce the attractiveness of the offers made by its competitors. ${ }^{152}$

Not all strategic behavior is socially harmful, and much of it is competitive. In general, however, strategic behavior is harmful and raises antitrust concerns when it reduces the attractiveness of the offers against which the strategizing firm must compete without producing substantial gains in productive efficiency to the strategizing firm. When socially harmful strategic behavior is successful, the firm engaging in the behavior earns monopoly profits, and competitors (or potential competitors) and customers pay the bill. ${ }^{153}$

Hovenkamp's conclusion that strategic behavior may be anti-competitive is supported by Porter's discussion regarding competitive moves $\mathrm{m}$ an ohgopolistic market. The dependency of small firms on a dominant firm poses a strategic dilemma for the oligopolist. If the dominant firm pursues pure self-interest, it risks destabilizing retahation for a cliance of greatly enhanced performance. Alternatively, if it pursues the interests of the industry, stability will yield a predictable, altliough lesser, amount of profitability. ${ }^{154}$

Because a firm's strategic beliavior may be driven by such a desire for stability as well as profit, its action may not fit within applied price theories of antitrust that focus on self-interested profit motives. ${ }^{155}$ Porter's recommendations for lessening the impact of competitive forces, chiefly rivalry and potential entry, and his factoring of emotional, historical, social, and managerial features into gnidelines for strategic analysis,

151. Id. at $97-98$.

152. See Hovenkamp, supra note 66 , at 260. See also Williamson, supra note 141 , at 274-75 \& 289-93 (describing ways to diagnose "offensive" strategic behavior that violates the antitrust laws); Williamson, Antitrust Enforcement: Where It's Been, Where It's Going, 27 ST. LouIS U.L.J. 289, 298-314 (1983) (surveying theories of strategic behavior); Baxter, Reflections upon Professor Williamson's Comments, 27 ST. LouIS U.L.J. 315 (1983) (cautioning against using strategic behavior analysis to promote more intensive antitrust enforceinent).

153. Hovenkainp, supra note 66 , at $260-61$ (footnotes omitted).

154. M. PORTER, STRATegy, supra note 140 , at 89.

155. See Williamson, supra note 141 , at 271-89. 
confirm that the "stability" a firm pursues may be measured in terms other than profit.

Porter also discusses optimal market shares and the role "good" competitors can play in a market-supporting and stabilizing a desired structure. ${ }^{156}$ Porter shows that a dominant firm will not necessarily charge a monopoly price but will imstead price at a level just high enough to avoid attracting "bad" competitors-those who would bring destabihizing rivalry to the market. ${ }^{157}$ His discussion of limit pricing behavior suggests that firms may be as motivated to seek competitive peace as monopoly profits. Strategic behavior analysis allows firms to identify and pursue competitive peace. As Professor Hovenkamp suggests, when such moves allow higher than competitive returns without enhancing productive efficiency, antitrust enforcers should become concerned. ${ }^{158}$

\section{B. Industry Structure and Concentrated Markets}

Porter's descriptions of industries and means of identifying strategic choices within those industries offer diagnostic devices to antitrust enforcers. Porter's methodology demonstrates how successful firms use industry structure to outperform their rivals. In subsection 1, I briefiy describe the characteristics Porter uses in analyzing market structure. In subsection 2, I adapt Porter's industry mapping techriques to identify market structures valued under the congressional model described in Part I above. Pre-merger and post-merger maps illustrate shifts to market structures that provide dominant firms the ineans to injure rivals. In subsection 3 I discuss several antitrust applications of Porter's analysis.

\section{Characteristics of Industry Structure}

Porter identifies thirteen "strategic dimensions" along which a firm's strategic decisions can be categorized. ${ }^{159}$ These dimensions outlime an overall picture of a firm's strategic position in an imdustry. They reflect considerations that traditional econoimic theory ambiguously

156. See M. PorTer, ADVANTAGE, supra note 140, at 225-26.

157. Porter describes strategies for developing and maintaining an optimal configuration of competitors in an industry. An optimal configuration is made up of good competitors who generate ininimal rivalry. Maintaining such a structure requires strategic moves including pricing decisions which deter the entry of "bad" competitors. See id. at 218-26.

158. See supra text accoinpanying note 153 .

159. (1) Specialization; (2) brand identification; (3) push v. pull ("the degree to which [a firm] seeks to develop brand identification with the ultimate consulner directly versus the support of distribution channels"); (4) channel selection; (5) product quality; (6) vertical integration; (7) cost position; (8) service position; (9) price policy; (10) leverage; (11) relationship with parent company; (12) relationship to home community and host government; and (13) technological leadership. M. Porter, Strategy, supra note 143, at 127-29.

Professor Williamson has identified a sinilar list of categories of firm decisions. See Williamson, supra note 141, at 291. 
describes as "product differentiation," the process by which a firm distinguishes its product from others in the marketplace. ${ }^{160}$ Porter observes that, as a rule, the deployment of resources along strategic dimensions applied by a particular firm is internally consistent. Thus, the deployment of firm resources within an industry yields discernable patterns of strategic behavior. ${ }^{161}$ These patterns identify strategic groups, clusters of firms that follow similar deployments. Although complete divergence is not implausible, most mdustries include only a few groups. ${ }^{162}$

\section{Mapping Industry Structure}

\section{Porter illustrates the mterrelationships of the various industry char-}

160. Porter's work reveals two key determinants for distinguishing strategic groups. The first is the firms' relationships to parent organizations. Different management objeetives will be reflected throughout strategic deployment. Id. at 130. The second determinant reflects the first: the segment of the industry the firm has chosen to serve. Industry segments differ from strategic groups in that, initially, they stand as diagnostic devices. The industry can be divided into sub-units for the purpose of developing an appropriate strategy. Rather than being defined by the marketing decisions of firms, they encompass broader considerations of structure: buyer type (size, industry, strategy or demographic), buyer geographic distribution, distribution channel employed, and product variety (including potential and substitute products). M. PORTER, ADVANTAGE, supra notc 140, at 238.

The structural attractiveness of particular segments is then identified by matching the firm's capabilities with the behavior of purchasers and the costs of serving those purchasers. Structural attractiveness represents the potential profitability of a firm in a particular market. It is a function of the firm's position and capability vis-a-vis the segment, segment size and growth and the productive interrelationships between that segment and another which the firm may already serve. Id. at 266.

161. M. PORTER, STrategy, supra note 140, at 130. Industry segmentation becomes a strategic device. The firm selects a particular segment because of its ability to perform in that segment. Performance is enhanced by strategic moves within that setting. The five competitivc forces may be chilled by a strategy of segmentation-limiting produetive activities to the boundaries of a segment while building barriers around that segment and concentrating on the rivalry dynamic among firms operating within it. See M. PORTER, ADVANTAGE, supra note 140, at 231 (describing focus as the main strategy for segmenting industries); Davidson, supra note 62, at 458.

As a diagnostic tool, "segmentation variables" incorporate the same concerns as traditional relevant market analysis. An example of distinctions within the variable categories can be found in the Jorde and Harris criticism of the Justice Department's assumption that all market exchanges are impersonal. See Harris \& Jorde, supra note 5, at 477. The authors identify six types of inarkets along which the buyer/seller relationship varies: (1) auction markets-identities unknown, transaction lacks historical context; (2) bidding markets-differ only in that one party is no longer disinterested in context; (3) relational markets-parties known to each other, potential or prior dealings may impact terms of exchange; (4) contractual inarkets-small range of products, but relationship transcends single transactions; (5) franchise markets-wider range of products involved, relationship effected accordingly; and (6) obligational markets-contractual relationship spanning a period of time, service oriented, renegotiations effected by relationship dynamics of last period (labor markets).

162. Porter argues that a firm's deployment decisions are necessarily driven by certain features of industry structure. Of the multitude of factors contributing to the five competitive forces, certain characteristics of the environment must be viewed as given-firm behavior cannot alter their impact on the range of competitive responses available to competitors. Through deployment of resources along strategic dimensions, a firm will attempt to affect those industry characteristics which are easiest to change and to defend. M. Porter, Advantage, supra note 140, at 130-52. 
acteristics with strategic maps and segmentation matrices. ${ }^{163}$ I propose to combine the two, with slight variation, for use in identifying mergers that create industry structures that allow merged firms to mjure their rivals.

The different costs of serving particular purchasers are a function of the strategic dimensions discussed above. For example, in a market where speciahization is important, certain buyers may require products that cost much more to manufacture than those required by other consumers. Analysis of the way an industry divides and serves various seginents shows that a firm's production choices are further constrained by industry structure. The relative deployment of resources to key dimensions is therefore himited by the segments a firm chooses to serve. The relationships of resource requirements can be laid upon the segmentation matrix thus: ${ }^{164}$

Figure 1

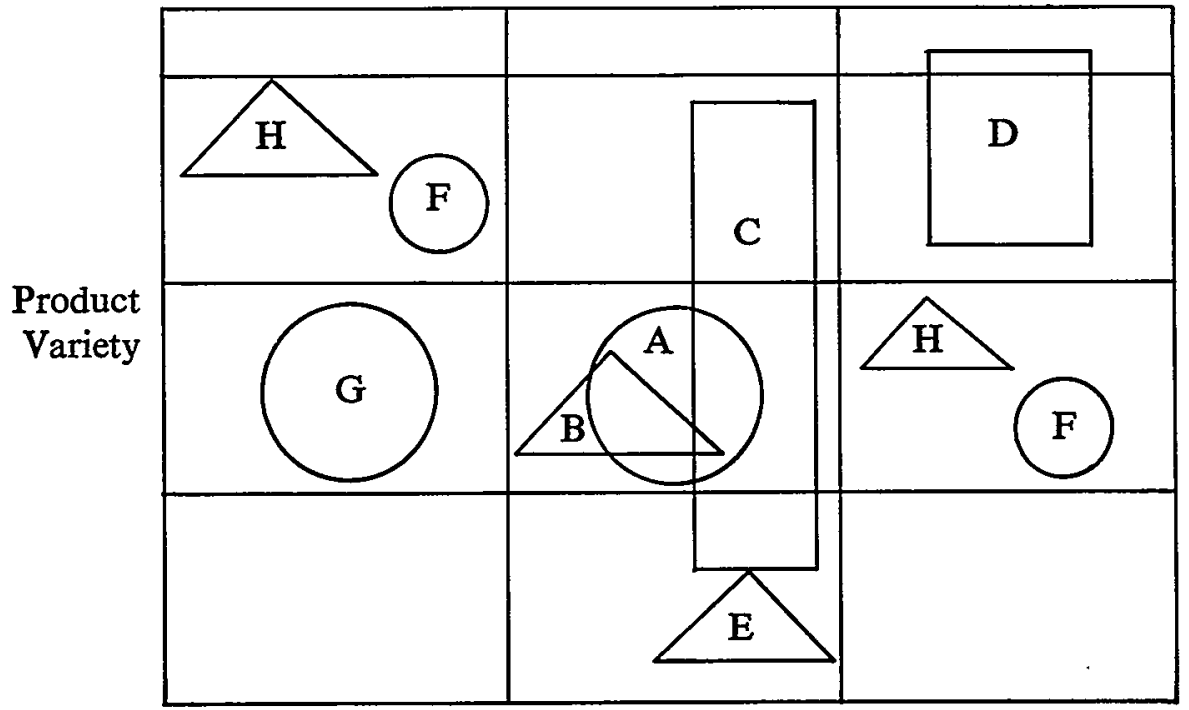

Consumer Type

Reading Figure 1 as a model of the kitchen apphance industry, the product variety imcludes dishwashers, refrigerators, stoves, ovens and

163. See M. Porter, Strategy, supra note 140 , at 140-41; M. Porter, Advantage, supra note 140 , at $248-55$.

164. M. Porter, Advantage, supra note 140, at 233 (discussing graphic representation of differences in firm resource requirements). I have combined Porter's two mapping techniques to show the spatial relationships most relevant to merger analysis. The grid defines the market segments, which identify the relevant consumers served by each firm. The shapes and their placement within the segment represent different firms' distribution of resources to serve buyers in the particular segment. 
garbage disposals. An additional range of distinguishable products exists within each segment (for example, microwave, gas, and electric ovens), any portion of which may be served by a particular firm or group. The segments themselves are distinguished in that the impact of each of the five competitive forces differs from segment to segment. Porter contends that product differences create segments if the differences affect at least one of the competitive forces. ${ }^{165}$ The horizontal axis reflects the different types of consumers. ${ }^{166}$ One segment includes institutional buyers of ovens, another includes premium domestic buyers of dishwashers. The various shapes represent different strategic groups within the industry, groups internally similar in the way they deploy resources. Size is proportional to the group's market share. Within the group, market shares and strategic responses to structural events or competitive moves tend to be similar. ${ }^{167}$

Figure 1 illustrates two points of interfirm contact that contribute to the dynamic equilibrium discussed in Part $\mathrm{I}$. The first point reflects distinctions for consumer evaluation; it is illustrated by the overlap of different shapes, the segment where groups are "interdependent." Porter concludes that intense competition occurs where "several equally balanced strategic groups, each following markedly different strategies, are competing for the same basic customer."168 Groups A, B and C, above, can expect "constant warfare." 169 Groups $\mathrm{H}$ and $\mathrm{F}$ can expect a more "stable (and profitable)" situation because the few nearby strategic groups each compete for distmct customer segments with strategies that may differ on only a few dimensions. ${ }^{170}$ Groups $D$ and $G$ are least affected by rivalry im that each is the sole occupant of the segment in which it competes.

The instability characteristic of markets with interdependent groups, the "vigorous competitive skirmishing"171 Porter counsels competitors to avoid, is strikingly similar to the dynamic econoinic inodel endorsed by the legislative history of the Clayton Act. Porter identifies

165. See id. at $234 \& \mathrm{n} .4,235$ (describing product differences and segmentation and distinguishing, for example, segment including console televisions from that of portable televisions).

166. My application of matrix modelling differs from Porter's. Analysis of segment definition can be more detailed, as Porter demonstrates. See M. PORTER, STRATEGY, supra notc 140, at 129 55. For purposes of the hypothetical discussed here, the combined matrix is introduced as a device for marking off the segments in which firms compete.

167. Id. at 130 .

168. Id. at 140 .

169. "Firms pursuing widely different strategic approaches tend to have quite different ideas about how to compete and a difficult time understanding each others' behavior and avoiding inistaken reactions and outbreaks of warfare." Id.

170. Id. at $140-41$. The different segments the two occupy, although representationally distinct, may have some similar characteristics inaking the dual service practicable.

171. Id. at $139-40$. 
price competition as the most "damaging" form of rivalry. ${ }^{172}$ Other forms of "jockeying for position" between interdependent groups include "advertising battles, product introductions and increased customer service or warranties." 173 Porter recommends these behaviors as strategically preferable because they may well increase demand by increasing the level of product differentiation in the industry, thus leading to a less interdependent structure. The congressional model prefers the interdependent structure of groups A, B and C. Strategic inergers designed to transform interdependent configurations into structures represented by the $\mathrm{D}, \mathrm{H}$ and $\mathrm{F}$ configuration, therefore, are contrary to the purpose of the Clayton Act. ${ }^{174}$ Merger law should be concerned with preventing strategies intended to proinote such structures.

The second point of competitive pressure arises from the contact between firms within the same strategic group. Strategic behavior analysis suggests that within strategic groups, "tacit agreements inay become easier and perhaps even natural." 175 Because resource deployinent along strategic dimensions is parallel for firms in the same group, developing coinpetitor profiles is extremely easy. Within such an environment, firms will begin to identify "good" coinpetitors and "bad" competitors. ${ }^{176}$ A good competitor is credible and viable and has clear self-perceived weaknesses that reduce the likelihood that it will challenge group organization. A good competitor understands industry rules, makes realistic assumptions regarding the industry, knows its costs and faces inoderate exit barriers (high enough to discourage new entrants, but not so high that it would fight rather than leave the inarket itself). ${ }^{177}$ Furthermore, the goals of a good competitor are reconcilable with those of the other firms in the group; the coinpetitor has a moderate stake in the strategy, comparable profit objectives (reducing the likelihood of price cutting), accepts current profitability, and is risk averse. ${ }^{178} \mathrm{~A}$ good competitor is distinguishable from a bad competitor, in part, because its strategy iinproves industry structure. By competing on quality and product differentiation, the good coinpetitor helps to raise entry barriers. ${ }^{179}$ The bad competitor undermines the industry or a firm's position in the group by

172. Id. at 17.

173. Id.

174. The configuration itself is not contrary to the Clayton Act. Natural growth toward the D, $\mathrm{H}$ and $\mathrm{F}$ configuration would evidence consumer confirmation of the strategic differences it represents. Attaining the configuration through merger would conflict with the Congressional design set out above.

175. See Davidson, supra note 62 , at 459.

176. See M. Porter, Advantage, supra note 140, at 212-15.

177. Id.

178. Id.

179. Id. 
breaking down distinctions, cutting price and lowering quality. ${ }^{180}$ The bad coinpetitor thereby contributes to the dynamic environinent Congress intended to proinote. The Clayton Act protects bad coinpetitors as well as interdependent groups.

\section{Implications for Antitrust Enforcement}

A strategic group inade up of good coinpetitors will be stable and profitable as long as it can defend its position. As Porter concludes: "[A] strategic group that has a large collective share and/or targets its efforts to distinct inarket segments not served by other strategic groups and achieves high product differentiation is likely to be inore insulated froin intergroup rivalry."181 To inaintain profitability, these isolated groups must build what Porter calls "mobility barriers" to prevent intergroup rivalry due to potential group entry. ${ }^{182}$ Mobility barriers provide an insulated group the ability to raise profits by lessening the impact of coinpetitive forces. ${ }^{183}$ Barriers obstruct intraindustry as well as intergroup movement and pressure, ${ }^{184}$ thus minimizing the impact of the dynainic environment valued in the congressional model of econoinics.

Barriers around one group can function to lessen the iinpact of the competitive forces that continue to disrupt the stability of other groups in the same industry. The higher the mobility barriers protecting a strategic group, the less vulnerable the group is to substitute products; as a corollary, the less exposed the group is to rivalry from other groups, the higher the average profit potential of firms in that group. ${ }^{185}$ Within that setting, a group gains "power" in a sense fainiliar to antitrust analysts. ${ }^{186}$ Power in relation to coinmon suppliers and buyers is a function of the group's vulnerability to suppliers and buyers coinınon to other groups. ${ }^{187}$ Power in this sense differs from the classic formulation of monopoly power only in that here it focuses on the difference between a product's price and that of the next highest priced substitute for that product.

Courts do recognize these "submarkets" as the relevant markets in

\footnotetext{
180. Id. at 217.

181. M. Porter, Strategy, supra note 140 , at 140.

182. Id.

183. Id. at 143 .

184. Id. at 132 .

185. Id. at 142 .

186. Antitrust cases define "monopoly power" as the power to control price or exclude competition. E.g., Berkey Photo, Inc. v. Eastman Kodak, Co., 603 F.2d 263, 272 (2d Cir.) (citing United States v. E.I. du Pont de Nemours \& Co., 351 U.S. 377, 391 (1956)), cert. denied, 444 U.S. 1093 (1979); see also Areeda, Monopolization, Mergers, and Markets: A Century Past and Future, 75 CALIF. L. REV. 959, 959-60 (1987) (comparing economists' and jurists' definitions of market power).

187. M. Porter, Strategy, supra note 140, at 137. Of course, power also hinges on the relative bargaining power of different suppliers and buyers due to the structure of their own industries. $I d$.
} 
some circumstances. ${ }^{188}$ Professor Areeda argues that "submarkets" should be viewed as the relevant market when the behavior of the firms competing in that market supports such a conclusion. ${ }^{189}$ If a strategic group is able to remove choice from the consumer by exercising power within a submarket, this power may be contrary to the congressional model outlined in Part I because it will skew development in that submarket. Limited only by pressure from outlying groups, isolated groups operate within a window of discretion, unhampered by responsive competitive forces.

Professors Harris and Sullivan refer to this window of discretion as "industry peace."190 This term suits the strategic behavioralist's view that monopoly profits are not the only goal of competing firms' management. Stability and the resnlting profitability combine to inotivate firm managers. The view is rational. To the manager, competition is less stressful when acceptable profits can be earned by maintaining the status quo rather than by responding imiovatively to the strategic changes of others. Part I of this Comment deinonstrates, however, that Congress valued the dynamic enviroument enough to conclude that firms should not be allowed to escape competitive forces simply by accuinulating capital and purchasing structural position. The Clayton Act favors internal growth, even in the pursuit of "peace," because such growth is continually monitored through consumer choice. The spoils of peace should go to the victor until it abuses its position in violation of the Sherman Act.

In keeping with antitrust legal tradition, Congress viewed firm position in terms of size and inarket share. Porter, however, teaches businessmen that the optimal configuration for peaceful operations is as much a factor of industry structure as it is of share. ${ }^{191}$ Porter reports empirical research that shows that the relationship between profitability and share depends upon the industry examined. ${ }^{192}$ His analysis lists market characteristics that suggest that a dominant firm need not maintain a particularly large inarket share to attain the peace associated with optimal structural configuration:

(1) Few economies of scale.

(2) A modest learning curve.

(3) Unattractive market segments.

188. See Aspen Skiing Co. v. Aspen Highlands Skiing Corp., 472 U.S. 585, 597 (1985) (quoting trial court's jury instructions).

189. Areeda, supra note 186 , at $979-80$.

190. Harris \& Sullivan, supra note 5 , at 892.

191. M. PORTER, ADVANTAGE, supra note 140 , at 221.

192. M. PoRTER, STRATEgY, supra note 140 , at 146 . Porter concludes that firm profitability is a function of three determinants: (1) common industry characteristics (the determinants of the five competitive forces); (2) characteristics of the strategic group (mobility barriers and group interdependence); and (3) the firm's position within that group (degree of intergroup competition, relative scale of firms, reliability of economies, operational capabilities to execute strategy). Id. 
(4) Buyers demand more than one source.

(5) Distributors have bargaining power and desire multiple suppliers.

(6) Competitors are simgle business firms who cannot share activities.

(7) "Followers" are required to ensure credible deterrence of bad competitor entry.

(8) "Followers" need meaningful shares to be viable.

(9) The imdustry has a history of antitrust scrutiny. ${ }^{193}$

Porter describes a strategy of segmentation through which firms may attain the optimal configuration for a given group in a particular industry. As Porter suggests, "[c]hanges im the structure of the industry can either facilitate the formation of new strategic groups or work to homogemze [existing] groups." 194 Segmentation strategy allows a firm to move strategically to insulate its strategic group from the pressures of interdependence. After insulation is achieved, discipline within the group will be a function of structure and of the tacit collusion of members' common strategy as to market share. With a disciplined peace in place, competitive pressure is highly uulikely. Without transgressing Sherman Act himitations, firms may profit from anticompetitive structures. Mergers aimed at segmenting an industry or at establishing optimal configuration within segmented markets, therefore, are the proper concern of Clayton Act enforcement. ${ }^{195}$

Porter's research sheds new hight on the Clayton Act's concern over concentrated markets. If peace can be obtained with lower shares, then tacit collusion is likely to occur im some industries at lower concentration levels. A firm's desire for peace and the availability of strategic behavior analysis and counseling ${ }^{196}$ are likely to imduce the firm to act strategically

193. M. Porter, AdVANTage, supra note 140, at 222.

194. M. PORTER, StRategy, supra note 140 , at 136 .

195. See Davidson, supra note 62, at 462 ("[G]reater problems with segmentation can be expected as the recommendations of business analysts like Porter become increasingly persuasive to executives."); Cal. Bus. Weekly, Mar. 2, 1987, at 1, col. 3 ("A fast-talking consulting firm rep says that his firm can tailor-make a strategy which will chart out the direetion and scale of your R \& D and production.").

196. In a 1983 article based in part on Porter's Strategy, Davidson argued that segmentation of a market should be included in Justice Department guidehine analysis under the category of "other" considerations the Department will inake in addition to coneentration strategies. See Davidson, supra note 62.

A recent comment by Professor Kahn suggests that segmentation by merger is occurring in ways government enforcement policy currently overlooks. See Kahn, supra note 106, at 1062-68. Kahn suggests ways in which the large firms in a concentrating market could merge in direetions prompting parallel competitor response. As a paradigm, Kahn describes airline industry trends toward concentration, viewed by the Department of Transportation as a natural post-regulation shake-out not requiring antimerger enforcement, as a process in which airlines effectively are dividing up markets through their hub-and-spoke organizational structures. Id. at 1063-64. Kahn's thesis is that the industry enforcement buzzword, "contestability," is not a sufficient determinant for protecting the interests of consumers. Id. at 1061. Current enforcement evidences a major weakness in merger analysis-the measurement of coneentration. See Harris \& Jorde, supra note 10 (critiquing various methods of market definition and measurement of market power). The debate 
to gain that peace. Policymakers must apply strategic behavior analysis to set limits for such behavior, limits based on the model established by Congress in creatimg the Clayton Act.

\section{III \\ Strategic Moves That INJURE COMPETItors}

Porter views industries as both dynamic and commimicative. A firm can interpret signals and quell industry turbulence by identifying dissatisfied or unserved consuiners and changing the offering it makes to those consumers. Congress designed the Clayton Act to protect such behavior. In other circumstances, however, firms defend their position or that of their strategic group without changing their offerings. Such behavior may be contrary to the values enbodied in the Clayton Act. Behavior that disciplines Porter's "bad competitor," the competitor who disturbs the industry peace of a strategic group or seginent, would be of particular concern to Congress's design. As I argued above, Congress intended to protect coinpetitors who spur improvements in the products offered to consumers.

In this Part, I demonstrate how competitors can apply strategic behavior analysis to show antitrust injury. In Section $A, I$ address the admissibility of strategic behavior evidence. In Section B, I provide examples of strategic mergers that injure coinpetitors of the inerging firıns. Such competitors fall within the class of firms Congress designed the Clayton Act to protect.

rages over whether airlines compete nationally, in which case concentration is low, or between city pairs, in which case inost of the major airlines have inonopoly control in certain markets. Kahn argues that mergers have yielded several airlines monopoly profits from certain routes which they use to subsidize competitive routes. Viewing concentration in terms of the transactional inodel that concerned Congress, market failures are causing consumers to make econoinic decisions based on skewed information.

In terms of injury to competitors, Kahn identifies an industry trend of competition by preemption, a strategy which is actually less than competitive. See id. at 1064. Such strategic preemption fits nicely within Sen. Kefauver's description of anticompetitive behavior. See supra text accompanying notes 96-100. Large airlines are finding that their hub-and-spoke organizational structures require the support of feeder routes which they had not previously developed. Feeder routes bring passengers from outlying airports to hubs via small planes. The passengers then board large planes for the major part of their transcontinental flights. Instead of competing for feeder routes, the major airlines have begun to purchase entire systems by mergers-United/Pan Ain Pacific, Texas Air (Continental)/New York Air (castern U. S. feeder)/Frontier (western U. S. feeder), and most recently, USAir/Piedmont. The coercive effects of such concentration are evidenced by Delta's reluctance to complete its recent merger with Western. Kahn observes that Delta had no choice but to mimic the merger strategy it competitors were implementing. Id. at 1064. The route systems being developed by other transcontinental airlines-United, Texas Air and American-required that Delta assure itself feeder routes in the western U.S. or face the prospect of flying half empty planes from west to cast. Id. The result was to further reduce consumer options and also to minimize diversity and competition among transcontinental carriers. Id. at 1064-67. 


\section{A. Admissibility of Strategic Behavior Evidence}

As set out above, ${ }^{197}$ this Comment applies the following standard of injury for merger hitigation:

To have standing to seek injunction of a inerger, a competitor must advance a credible theory that:

(1) there is a reasonable probability that the inerger puts the merged firm in a position to restrict the competitive choices available to its competitors without changing the quality or price of its own products, or

(2) there is a reasonable probability that the merger will give rise to market structures that could allow the merged firm to exploit such an anticompetitive position.

While inost antitrust theorists acknowledge that anticompetitive strategic behavior occurs, some conclude that the issues involved are too complex to be dealt with in antitrust litigation. ${ }^{198}$ Such refusal to address the complexity of strategic behavior ignores the success of courts that have confronted one form of strategic behavior, predatory pricing, by imposing a series of presumptions to reduce analytical difficulties. ${ }^{199}$ In inerger litigation, the issue before the court is simply whether the postmerger market allows the defendant to act strategically in a manner that targets plaintiff or all competitors similarly situated (plaintiff's group). The inarket analysis evidence required to identify strategic behavior is no more coinplicated than the market definition required by current antitrust doctrine as part of every plaintiff's prima facie case. ${ }^{200}$

Currently, courts admit certain evidence determined relevant by standards set out in United States v. Philadelphia National Bank..$^{201}$ Defendants rebut presumptions of illegality that arise due to statistical concentration evidence by presenting analyses of the structure, history and probable future developinent of the market. ${ }^{202}$ In United States $v$. General Dynamics, the Supreine Court applied structural evidence to reach a finding that, in the case before it, market shares were an unreliable indicator of market power because of the prevalence of long-term requirements contracts in the coal industry. ${ }^{203}$ In Cargill, the Tenth Circuit held that the district court properly ignored structural evidence

197. See supra text at page 2089.

198. See Baxter, supra note 152.

199. See William Inglis \& Sons Baking Co. v. ITT Continental Baking Co., 668 F.2d 1014, 1033-40 (9th Cir. 1981), cert. denied, 459 U.S. 825 (1982); see also Harris \& Sullivan, supra note 5, at 892; Williamson, supra note 152, at 302-13.

200. See M. Porter, StrategY, supra note 140, at 5-33; see also Williamson, supra note 141 (urging the importance of adapting antitrust analysis to focus on strategic behavior).

201. 374 U.S. 321, 362-63 (1963).

202. Id; see also Brown Shoe Co. v. United States, 370 U.S. 294, 320-21 (1962) (finding that Congress desired courts to view the effects of a merger functionally, within the context of a particular industry).

203. 415 U.S. 486,499 (1974). 
because sucli evidence did not cliallenge the reliability of historic information defendants used to compile statistical representations of market concentration, nor did it qualify those statistics as did the long-term contracts admitted in General Dynamics. ${ }^{204}$ Nowhere did the Tenth Circuit suggest that the structural evidence should be excluded as too complex.

Strategic beliavior evidence focuses on past and future market structure. It documents behavior that could harm a competitor in a manner Congress designed the Clayton Act to prevent and, thus, is directly relevant to establishing antitrust imjury. Admission of strategic behavior evidence could be regulated adequately in higlt of the Philadelphia National Bank Court's insistence that merger analysis stay within the predictable bounds of legal and economic certainty. ${ }^{205}$ The admission of such evidence upon an offer of the plaintiff inerely requires a variation of the current presumption: strategic behavior evidence should be admitted when statistical concentration evidence is sufficient to illustrate the anticompetitive effects of a merger. Although this standard would not always prevent the umrecessary presentation of mammoth evidentiary proofs, other standards for determining whether a particular claim is spurious remain applicable.

\section{B. Strategic Behavior Theories of Antitrust Injury}

Merger may be a strategic behavior desigued to change industry structure to favor the merged firm. Porter contends that firms can observe, predict, and alter industry structure. ${ }^{206}$ As discussed above, changes in structure can either facilitate the formation of new strategic groups or work to make existing groups more homogeneous. ${ }^{207}$ Porter identifies four "strategic opportumities"-goals a firm may seek to achieve through strategic moves: (1) creating a new strategic group; (2) shifting to a more favorably situated group; (3) strengthening the structural position of the existing group or of the firm within that group; and (4) shifting to a new group to strengthen that group's position. ${ }^{208}$ Because industries evolve, such opportunities present themselves in different forms over time, requiring different responses. ${ }^{209} \mathrm{~A}$ firm's ability to restructure an industry through strategic merger enables it to seize

204. Monfort of Colorado, Inc. v. Cargill, Inc., 761 F.2d 570, 580 (10th Cir. 1985), rev'd, 107 S. Ct. 484 (1986).

205. Id. (citing Philadelphia Nat'l Bank, 374 U.S. at 362).

206. See M. Porter, Strategy, supra note 140 , at 187.

207. Id. at 136; see also supra note 141 and accompanying text.

208. M. PORTER, STRATEGy, supra note 140 , at 150 .

209. Id. at 136 (for example, as an industry matures, consumers become less dependent on manufacturing. and service or full-line distribution of peripherals become important for reassuring potential repeat buyers). 
such opportunities and avoid the evolutionary pressures of the market. ${ }^{210}$ If merger were not available, the changes in market structure would be the result of internal growth, a function of introspection, innovation and expressions of consumer confidence. Clearly, Congress intended to permit smaller firms to merge in response to the pressure of economies of scale. ${ }^{211}$ If such economies are not demonstrable, however, claims of possible efficiencies may simply be obfuscations of the merger's true strategic purposes. As Professor Williamson observed,

There are at least two kinds of mergers with strategic purposes. First, the merger of two adjacent firms in competitive space will avert head-to-head competition. Second, merged firms are better able to focus replies to new entry and effect deterrence than if the two firms remained independent. $^{212}$

Strategic behavior analysis can help identify such mergers and the ways in which they can harm the merging firms' rivals.

The segmentation strategies discussed in Part II constitute a major threat to the congressional model of a dynamic economy. Successful segmentation can greatly lessen the intensity of intergroup rivalry. A merger that furthers seginentation and allows the merged firm to coerce other firms serving that segment to reduce rivalry should be identified as injurious.

Porter discusses four factors that determme the intensity of intergroup rivalry. ${ }^{213}$ These factors provide criteria for identifying markets in which segmentation can lessen rivalry. These criteria should be distin-

210. Commentators critical of the Chicago School label strategic mergers Type $\mathrm{C}$ mergers. Type A mergers are those that classic theory attempts to restrain, mergers yielding statistical market power and thus the ability to collude. Type B mergers enhance economies of scale and consequently do not run contrary to congressional intent. Current enforcement application of Chicago theory has led to a greater number of mergers being classified as Type B; the Justice Department's Merger Guidelines fail to account for Type $C$ mergers where price effects are localized in terms of market segments in which merged firms perform strategically to resist intrusion and to discipline rivals more effectively than they had been before the merger. See Williamson, supra note 141, at 286-87.

211. See supra notes $88-100$ and accompanying text.

212. Williamson, supra note 141, at 286 (emphasis added). Professor Williamson suggests that strategic mergers are likely to increase concentration levels above guideline thresholds and thus are likely to be challenged by government enforcement. He points out, however, that the government's decisionmaking processes may be defective in that they stress the importance and identifiability of allocative efficiencies while failing to account for the "relevant spatial features of markets." Id. His conclusion that the guidelines fail to account for strategic mergers is apparently based on this potential enforcement flaw. See supra note 210 . Williamson's premise that high concentration and high barriers to entry are prerequisites for firms to act strategically, however, is based on conclusions he drew before Porter illustrated that structure can lower the concentration required for firms to achieve peace. See supra notes 191-93 and accompanying text. Williamson's premise should thus be discounted in some instances, and strategic behavior accorded more scrntiny than his writings would suggest.

213. See M. Porter, Strategy, supra note 140, at 138-41. Davidson derived similar criteria in his 1983 piece, but by substituting "firms" for "groups" neglected some of the more important aspects of Porter's analysis. See Davidson, supra note 62, at 458. 
guished from others relating to the market shares necessary for firms in a segmented market to maintain peace. The four factors are these:

(1) Number of Strategic Groups: If a market has more than one group, rivalry results. The greater the number of groups and the greater the similarity in their cumulative market shares, the greater the intensity of that rivalry (see number of shapes on Figure 1).

(2) Interdependence: If groups target the same customers, rivalry will be imtense (see overlapping shapes on Figure 1).

(3) Differentiation: If consumers view products as interchangeable, intergroup rivalry results (see number of grid sections on Figure 1).

(4) Strategic Distance: If deployment along key strategic dimensions diverges, rivalry will be vigorous (see different shapes on Figure 1). ${ }^{214}$

Porter's instructions for structural analysis are useful in assessing these criteria: $:^{215}$

(1) Map strategic groups in the industry; mapping identifies mobility barriers, marginal groups (potential entrants), directions of strategic movement (pre-merger and post-merger configurations), trends toward concentration (map illustrating different points in time), and reactions to changes. ${ }^{216}$

(2) Assess the height and composition of barriers protecting each group.

(3) Assess the relative bargaining power of each group in the industry vis-à-vis its buyers and suppliers.

(4) Assess the relative position of each group vis-à-vis substitute products.

(5) Assess the pattern of market interdependence among groups and their vulnerability to warfare mitiated by other groups.

Referring again to Figure 1, analysis of barriers should focus on the divergences between group locations. The horizontal axis of segmentation roughly indicates relative bargaining power of buyers, but supplier power requires analysis of a separate industry that cannot be illustrated in this type of diagrain.

Physical distance between groups represents product substitutability that may be defeated if segment boundaries intervene. For example, industrial and home kitchen apphances are imperfect substitutes.

The overlap of different shapes on the diagram indicates market interdependence. The existence of two non-overlapping groups serving one segment, like groups $\mathrm{H}$ and $\mathrm{F}$ on the diagram, illustrates vulnerability to interdependence. The illustration suggests that with minor alterations in resource deployment, these groups could target the entire segment. An exainple would be dishwasher manufacturers one group of which distributes only through multi-brand salesrooms and another

214. Figure 1 appears supra at 2093.

215. See M. PORTER, STRATEGY, supra note 140, at 126-55.

216. See id. at 154 . 
which supplies retailers who have developed their.own distribution systems-Sears and Roebuck, for example. Firms in the former group could easily compete $\mathrm{m}$ the latter merely by adding capacity; other resources would already be in place. Merger toward such a result could alter the composition of the latter group so that the former could communicate tlie terms of peaceful coexistence and even coerce a reduction of rivalry. Structural analysis suggests that to lessen rivalry, a merger would need to effect group imteraction or move group infrastructure closer to that configuration that is optimal for peaceful coexistencewhere few or no bad competitors press for conipetitive response.

Subsection 1 below sets out exaniples of mergers that would enable a firm to chill intergroup rivalry. Subsection 2 below sets out examples of group infrastructure that are closer to the optimal configuration. Subsection 3 discusses mergers that are desigued solely to duplicate the scale advantages of other firms in the market, mergers Congress intended to exenupt from the Clayton Act's prohibition.

\section{Intergroup Injuries}

The following are examples of ways in which a firm could use merger to chill competition from other strategic groups that overlap its targeted custoniers (interdependence) or that exist within its own or a similar market segment (peripheral pressure). Certain firms in each setting would be injured in ways contrary to the intent of the Clayton Act.

\section{a. Exposing Firms to the Elements}

Within a strategic group, scale may be a key deternimant of position simply because certain strategies impose higher costs on sniall firms than on large firms. ${ }^{217}$ At the same time, however, large firms can act as niarket-makers, bearing costs like advertising or research and developinent that smaller competitors need not duplicate to create or sustain a niarket. ${ }^{218}$ A strategic group in such an industry is hikely to be led by a dominant firm surrounded by multiple smaller competitors. The doininant firm supplies a "cost unibrella" that benefits smaller firms in its strategic group.

In a group led by a firm providing a cost umbrella, removal of the cost leader through merger with a dominant firn in an interdependent group allows the new firm to affect the conipetitive choices of snialler firms in both groups through nianipulation of that umbrella. ${ }^{219}$ While

217. Id. at 143; M. PORTER, AdVANTAGE, supra note 140, at 205-06.

218. This assertion corresponds to the conclusions of Scherer and Schumpeter on the innovative value of oligopolistic market structures. See Scherer, supra note 129, at 1010-12 (discussing J. SCHUMPETER, CAPITAlism, Socialism, AND Democracy (1942)).

219. See M. Porter, AdVANTAGE, supra note 140, at 205-06. 
such a position gained through internal growth and consumer confirmation of the leading firm's strategy might not give rise to Sherman Act concern, gaining such a position through inerger may run contrary to the Clayton Act. The acquiring firm's position merely confirms the ability of its management to manipulate financial reserves toward the strategic goal of acquisition. It will not have earned the benefits of a cost unbrella through management's ability to remvest those reserves toward innovation and coinpetitive progress. Congress designed the Clayton Act to prevent strategies of this type. ${ }^{220}$ Disciplinary actions of a firm gaining such a position injure the smaller firms contrary to the design of the Clayton Act. ${ }^{221}$ Firns that could be disciplined by a merged firm's manipulation of a cost umbrella should have standing to enjoin the inerger.

A hypothetical merger in the consuiner apphance industry illustrates such injury to coinpetitors and competition. In the apphance industry, two interdependent strategic groups coinpete to sell durable goods to the same inarket segment: residential purchasers of dishwashers, clothes washers and dryers, stoves and refrigerators. One strategic group offers a full range of installation, repair services, and extended warranties (the "full service" group) while the other distributes the same product hines but offers no additional service features (the "discount" group).

Because the groups' product lines are the same, intergroup.rivalry requires considerable advertising expenditure by both groups to distinguish their offermgs. Advertising in such an industry serves a dual function-promotimg the strategic group as well as the advertismg firm. ${ }^{222}$ Continuous advertising is necessary because consuiner loyalty wanes over the life of a durable good. Smaller firms in each group remain viable in part because the dominant firm, able to exploit advertising economies of scale, bears the cost of distinguishing its group's offering from that of the other group. In effect, the smaller firms operate under the promotional uinbrella of the larger. If the smaller firms are "good" competitors, the dominant firm has no desire to turn on them, and intragroup rivalry is minimal. 223

220. As developed above, Congress looked with disfavor on market dommation through acquisition of competitors rather than through internal growth. See supra notes 84-87 and 107-08 and accompanying text.

221. See supra notes 84-100 and accompanying text.

222. Cf. M. Porter, Strategy, supra note 140 , at 134 (heavy advertising can be used to differentiate groups within a previously undifferentiated industry).

223. A "good competitor" is a credible firm whose self-perceived weaknesses reduce the likelihood that it will challenge group organization. See M. PORTER, ADVANTAGE, supra note 140, at 212-15. A good competitor understands industry rules, makes realistic assumptions regarding the industry, knows its costs and faces moderate exit barriers (high enough to discourage entry, but not so high that it encourages warfare rather than fight). Good competitors help to present a credible 
By acquiring the dominant firm in the discount group and converting that firm's operations to a service orientation, the dominant firm in the full service group positions itself to injure smaller discount firms in the group. The merged firm could silence the discount market-maker while gaining resources to increase the frequency of the its own proinotional message. ${ }^{224}$ With the promotional umbrella gone, the smaller firms are forced to add to their advertising budgets. Instead of merely identifying themselves as discounters, the firms must shoulder the advertising burden of establishing the comparative value of a discount offering, and, at the same time, they must imcrease the frequency of their inessage just to be heard above the increased roar of the merged finn. The imcreased roar of the service group would attract more, less-informed, first-time buyers, and discount group market share would decline. Confronted with declining share and increased costs, discount firm management would be forced to consider a redeployinent of resources. ${ }^{225}$

The goal of an illegal strategic merger would be to create such indecision and to position the merged firm to stipulate an outcoine. While change and response to change are the functions of rivalry, strategic positioning that allows a dominant firm to narrow or stipulate the responses available to competitors actually reduces rivalry. Such positioning allows the dominant firm to orchestrate evolution in the market toward its preferred form of industry peace. The merger strategy discussed above would yield such a position. When a firn or group establishes a cost of doing business, like advertising, which is relatively constant between firms, that cost is susceptible to economies of scale and is purely strategic when imposed by non-market forces. ${ }^{226}$ Porter's research demonstrates that a dominant firm's reallocation of resources can inove other firms in imterdependent groups to the verge of responsive decisions to redeploy their own resources. Porter maintains that in interdependent groups, price in that group which has the highest mobility barriers is the key determinant of profitability for both groups. ${ }^{227}$ Because lower prices

strategy alternative to consumers by enhancing differentiation and broadening points of consumer access. Id. at 202-07.

224. The cost curve of the smaller firms in the discount group shifts upward because greater expenditure is required simply to maintain output. See id. at 19 (relative cost of differentiating is less for large firms than for smaller firms).

225. While increased information in the marketplace is in the best interests of the consumer in the short run, manipulating the amount of information presented to effect the costs confronted by smaller firms has other anticompetitive effects. As discussed below, baiting the smaller firms with "peace" could eliminate consumer information about choices as well as the choices themselves.

226. Hovenkamp, supra note 66, at 278-79; as to raising rivals' costs, see infra notc 249 and accompanying text.

227. Groups with high mobility barriers have greater profit potential than less protected groups. Where competition within the group is intense, however, profits will drop such that group members' enjoyment of both industry profits and group-specific protectionist profits are destroyed. $M$. PORTER, STRATEGy, supra note 140, at 145. 
(or higher costs through expenses like advertising) spill over from group to group via interdependence, less protected groups must respond and thereby reduce their own profits. ${ }^{228}$

In the hypothetical merger, the merged full service firm can increase or decrease the pressure exerted by the spillover cost of advertising, a cost to which weakened discounters are forced to respond. The merged firm thus can virtually direct the responses of firms in the discount group. The dominant firm could use its advertising message to assure that the discounters recognize their own weaknesses while selectively lowering entry barriers to encourage redeployment of discount firm resources toward the pattern supporting a peaceful group configuration. ${ }^{229}$ The dominant firm would then outline a miche in which discount management could once again enjoy a peaceful lifestyle. Baiting the smaller firms with peace would be easier than undercutting their costs and awaiting their demise. ${ }^{230}$ Such pressure is thus not as costly to the dominant firm as predatory pricing strategies, nor as likely to be punishable. Further, the struggle may be one of lesser imtensity since it pursues the limited goal of changing the smaller firms' behavior. But the strategy still injures discount firms by narrowing their choice of competitive moves. Even if discount firm management resisted an initial suggestion for peace, the dominant firm's control of a major cost factor would skew deployment of the discounter's resources and thereby limit the discounter's alternatives. The merger would substantially lessen conipetition because the dominant firm would gain the ability to control the direction of progress within the group, and perhaps to dictate market share and firm profit as well.

The proposed standard for Clayton Act mjury would be met if a competitor could show: (1) that a cost umbrella existed that would be significantly reduced by removal of the leader; and (2) that its own strategic group was interdependent with the strategic group to which the postmerger firm would belong. The substantive portion of the merger imjunction hearing would then focus on concentration ratios and, perhaps, the inability of the mjured firms to duphicate the cost umbrella because of relative size or some other limitimg feature. ${ }^{231}$ Proof of the latter would

228. Id.

229. Porter sets out ways in which the pattern of competitors can be influenced: technologies can be licensed; geography can be used as a criterion to retaliate selectively against firms with smaller profit margins (as signaling, not predation); coalitions can be formed for information transfers to draw new entrants and selectively lower learning curve barriers or assist in capital markets. M. PORTER, ADVANTAGE, supra note 140, at 219.

230. Alternatively, the merged firm inay indeed possess the resources to continue a strategy of acquiring weakened firms. It can pressure smaller firms that have been unable to communicate the value of their offering in the durable appliance market-a strategy of the type also condemned in the legislative history. See supra notes 91-100 and accompanying text.

231. This is not to say that current concepts of concentration account for all market strnctures 
be unnecessary if concentration ratios revealed that the government's approval of the merger had been an enforcement error. Such an error might arise because the Department of Justice or the FTC had failed to balance an efficiency justification against the merged firm's enhanced strategic position.

The injury described above corresponds to injuries discussed in the legislative history of the Clayton Act. ${ }^{232}$ It also illustrates the observations of commentators that the prophylactic, structural approach of the Clayton Act is particularly suited to preventing strategic behavior abuses in segmented inarkets-behavior otherwise unreachable by the antitrust laws. ${ }^{233}$ As Professor Davidson concludes,

[I]n Theatre Enterprises, the Supreme Court discussed the type of cooperative business behavior advocated by Porter, and declared that it had "never held that proof of parallel business behavior conclusively established [unlawful] agreennent. ..." Thus, once established, an effectively segmented and (anticompetitive) market structure may be immune from antitrust attack. ${ }^{234}$

Thus, an application of the Clayton Act stressing identification of strategic mergers inay be the only way to prevent the developinent of inarket structures that injure both competitors and competition.

in which injurious behavior becomes possible. The analysis I set out in this Comment necessarily relates to current concepts of substantive antitrust violation as well as addressing standing under the Clayton Act. While the scope of this Comment does not extend to a redefinition of the substantive violation, my analysis of Porter's theory of industry peace does suggest that behavior contrary to the Clayton Act may occur at lower concentration levels than current merger analysis finds offensive. See Harris \& Sullivan, supra note 5, at 892; see also supra notes $190-96$ and accompanying text (discussing industry peace). If strategic positioning through merger werc to be viewed as a substantive violation, the standard of proof for injunction might simply require that the theory of positioning presented to establish standing be suppleinented by some "plus" factor, for example, evidence showing an intent to abuse the new position.

232. Representative Yates argued,

The greatest danger to competition today [is] . . the growth of industrial oligarchies in which power over an industry is divided among thrce or four large concerns. When three or four producers take the places of 20 or 30 the chances are great that . . . declining markets will be dealt with by restriction of output instead of price reduction, that the big concerns will adopt a live-and-let-live policy toward each other at the sacrifice of their efficiency and their progress, and that the remaining small competitors will either be bought out or-reduced to vassals who meekly follow the large enterprises. We want competition, not business oligarchy.

95 CONG. REC. 11,493 (1949) (emphasis added); see supra notes 84-100 and accompanying text.

233. See Davidson, supra note 62, at 461 ; Williamson, supra note 141 , at 297 ("[E]ariier advice that the merger statutes be used to foreclose strategic hazards thus warrants renewed consideration."). Discussion in the legislative history of trends toward concentration might be born out under strategic inanipulation described above; removing the cost umbrella inight weaken a firm, thereby making it susceptible to secondary or tertiary inerger. See supra notes 88-100 and accoinpanying text.

234. Davidson, supra note 62 , at 460 . Tacit collusion is practically endemic in isolated strategic groups. See supra notes $169-76$ and accompanying text. 


\section{b. Discipline from the Outside In}

In an industry segmented according to product quality, producers of low-quality goods experience price pressure from goods sold in the highquality segment. Clearly, the price difference between segments must correspond to consumer perceptions of differences in quality. In such an environment, a doininant firm in one segment can merge strategically to acquire a significant portion of a neighboring segnient and position itself to discipline "bad" competitors in its home segment.

Discipline from the outside in can be demonstrated best by case example. Whirlpool Corporation's 1985 acquisition of Kitchen Aid was designed to be a strategic inerger. ${ }^{235}$ Whirlpool was a major producer of low-quality dishwashers. The firm marketed its dishwashers under its own brand name and also mamtained a large private label contract with Sears, which marketed the same dishwashers under another brand naine. ${ }^{236}$ Kitchen Aid, a subsidiary of Dart \& Kraft, Inc., produced high-quality dishwashers marketed exclusively under its own brand name. Pre-merger concentration in the dishwasher manufacturing industry was extreinely high. Because a few firms produced dishwashers that retailed under competing brand names, the four largest firms controlled a total of $93.5 \%$ of the market.

The dishwasher industry is made up of two distinct segments. Kitchen Aid viewed its product and its targeted consumers as distinct from those of general consuinption manufacturers. The firm refused to produce private-label goods for fear of damagnig its reputation for quality. Planning documents revealed that Whirlpool viewed the high-quality segment as serving a distinct group of consumers, customers to whom Whirlpool desired access. ${ }^{237}$

Motivated by shrinking domestic markets, Whirlpool was looking for a new class of dishwasher consuiners. In the apphance industry, high entry and exit barriers restricted inovement and existing manufacturers

235. The presentation here is gleaned from the district court opinion in White Consol. Indus. v. Whirlpool Corp., 612 F. Supp. 1009 (N.D. Ohio 1985), injunction vacated, 619 F. Supp. 1022 (N.D. Ohio 1985), aff'd, 781 F.2d 1224 (6th Cir. 1986), and Professor Williamson's commentary on the case. See Williamson, supra note 141, at 294-98. Professor Williamson served as a consultant to the plaintiff's side in White. While the analysis presented in White required a complicated series of deductions to conclude that dishwashers made up the relevant submarket in the white goods or major kitchen appliance industry, market definition is irrelevant to the purpose of this example. Assuming proper market definition, the case demonstrates how firms may merge strategically within a market.

236. Dishwasher production is actually a submarket of the larger white goods industry, which encompasses production of all major kitchen appliances. Most producers market a full line of white goods, from refrigerators to washers and dryers. In order to offer this line, manufacturers lacking facilities to produce certain products, as well as retailers without any production facilities, purchase white goods through private label contracts and market them under their own brand name.

237. Williamson, supra note 141 , at 297. 
possessed substantial excess capacity. Whirlpool was under pressure to compete for share in order to keep its plants operating, but was exposed to rivalry in its own segment due to "bad" competitors in its own strategic group. The suit brought by fellow low-quahty manufacturers White and Magic Chef to enjoin Whirlpool's acquisition is evidence of dissension in those ranks as to how the industry should respond to the changing market. Whirlpool needed to attract new customers and to develop a strategy for defending its position in the face of flat or declining demand.

While Whirlpool struggled to minimize the impact of intragroup rivalry, Kitchen Aid experienced no such pressure as the only firm occupying the sole strategic group serving the high-quality product segment. From its independent position, Kitchen Aid frustrated Whirlpool in two ways. First, Kitchen Aid's refusal to produce private-label goods evidenced its desire to remain autonomous and distinguished in the market place. Kitchen Aid thereby "signaled" the characteristics of a "bad" competitor. Kitchen Aid's message was that if Whirlpool itself were to enter the high-quahity segment, rivalry would be intense. Moreover, Kitchen Aid was the sole source of a comparative price ceiling. As such, Kitchen Aid was the main source of the intergroup rivalry effecting Whirlpool.

By purchasing Kitchen Aid, Whirlpool could position itself to solve its problems. It could enter the high-quality segment without engaging a competitor that specifically distinguished itself from manufacturers like Whirlpool, which chose not to specialize in high quality products. Whirlpool would also gain sole control of the group that controlled the comparative price ceiling over its home segment. The strategic importance Whirlpool placed on the merger is evidenced by the fact that the firm chose not to reduce its sizable offer after learning that Kitchen Aid's market share was actually half that upon which the original offer was based. ${ }^{238}$

Planning documents revealed that control of the price ceiling was Whirlpool's key motivation for the inerger: Whirlpool intended to market its lower quality dishwashers under the Kitchen Aid naine. Kitchen Aid's reputation could be put to use in disciplining rivals serving the lowquality segment. By lowering the actual quality of Kitchen Aid-label products, Whirlpool could shift Kitchen Aid's cost curve to create a greater margin between price charged and the cost of producing those goods.

The elimination of a high-quality competitor would broaden Whirlpool's opportunity to exploit market failures. Feedback from second-time dishwasher purchasers is minimal because, in addition to being

238. Id. at 295-96. 
expensive durable goods, dishwashers are kitchen fixtures-few purchasers replace kitchen fixtures twice during the time they own a home. Whirlpool could lower the price for "high-quality" dishwashers, activate its own excess capacity to respond to the increased demand, and thus force low-quality rivals to lose share or drop price according to the perceived quality gap. ${ }^{239}$ Failures in market communication would give Whirlpool time to implement a Kitchen Aid price reduction and to coininunicate desirable competitor responses-perhaps advertising the price reductions as temporary, signaling to coinpetitors that a return to a peaceful environment would follow their cooperative responses. ${ }^{240}$ Whirlpool's overall sales would not decline-virtually the same number of its units would be sold even if it did not drop the price of Whirlpool named goods because declining Whirlpool sales would be offset by increased sales of Kitchen Aid named goods.

Whirlpool's priorities in the transaction further demonstrated that Whirlpool sought to gain control of the price ceiling pressuring the low quality inarket. As a curative divestiture to ineet government opposition to the inerger, Whirlpool chose to sell Kitchen Aid's manufacturing capacity to Einerson. Clearly, Whirlpool was only after the Kitchen Aid name and inarket and had hittle desire to produce the high-quality goods previously available to consumers. The original terins of the curative sale limited Emerson's production and sale in such a way that the district court refused to consider the two companies as independent entities for purposes of market share. Once this flaw was remedied, the court approved the deal. ${ }^{241}$

Whirlpool also gained position to apply additional pressure to lowquality rivals in the forn of distributor leverage. The dominant firıns in the dishwasher inarket (GE as well as Whirlpool) had power over distributors because they offered a full-hine strategy in a inarket where consuiners demand inulti-line dealers. By requiring that retailers and distributors carry their entire lime or no part of it at all, and by including Kitchen Aid products in that demand, Whirlpool and its "good" coinpetitors could greatly reduce the floor space available to "bad" coinpetitors. Faced with the loss of a major brand-line and a ininor brand-line, a distributor would have little choice but to provide tlie additional space to the "good" competitor. Faced with foreclosure, declining share and

239. See M. Porter, Strategy, supra note 140 , at 143 (a firm may position itself so that skills and resources developed in one group give it a particular advantage in entering another).

240. Whirlpool's signaling techniques would be similar to those discussed in the hypothetical above. See supra notes 229-30 and accompanying text. Competition for private label contracts might provide it with additional lines of communication to other manufacturers and retailers.

241. The government had actually approved the merger with the exclusive rights contract intact. White, therefore, demonstrates the need for private enforcement of section 7 as a means of scrutinizing government enforcement. See White, 612 F. Supp. 1009. 
diminishing revenue, managers for White Consolidated and otler "bad" competitors would liave to decide whether to engage im costly warfare or to make the strategy clianges signaled by Whirlpool and return to a peaceful existence. ${ }^{242}$ Whirlpool's strategic restriction of White's ability to respond freely to changes $m$ the market is an injury that Congress intended to prevent in drafting section 7 of the Clayton Act. ${ }^{243}$

The ultimate correction that imight occur in the marketplace is of httle legal consequence. Even if White had the resources to consider combating the market failures Whirlpool would cause, Congress intended to protect coinpetitors like White from being compelled to take such resource-draining measures by a merger of rivals. ${ }^{244}$ Althougli the abuse of a trade name might seem more suited to resolution in an unfair competition settmg, it is clear that Congress imtended the Clayton Act to prevent the alterations in market structure that result from a merger enabling a firm to compete unfairly. ${ }^{245}$

\section{Intragroup Injuries}

The preceding discussion of intergroup discipline also describes the disciplime that a doininant firm might exercise witlin a strategic group to cliange "bad" competitors to "good." Except when interdependent, strategic groups may become so protected by entry barriers that beliavior within those groups parallels that within independent industries. ${ }^{246}$ Strategic behavior analysis identifies collusive structures that require as large a leading market share or as great a level of concentration as antitrust enforcers had previously believed necessary. ${ }^{247}$ The criteria set out above can be apphed to identify the level of concentration at which "peace" is maximized-the level at which antitrust enforcers should become concerned.

The discussion above demonstrates that tacit collusion may be endemic in markets configured for industry peace. If industry structure provides dominant manufacturers with leverage in the market of distributors, injury may take the form of the tacit collusion alleged in both American Tobacco and Theatre Enterprises: colluding firms applying disciplinary pressure by foreclosing a rebellious firm's access to distribution

242. Assuming that White was a "bad" competitor in Whirlpool's strategic group-that is, one that deployed resources in a strategically similar manner, but insisted on competing on price-the entry assistance strategy discussed above would not be necessary since there would be no "barriers" to good behavior.

243. See supra notes $88-100$ and accompanying text.

244. See supra notes 83-84 \& 87.

245. See supra notes $91-96$ and accompanying text.

246. See M. PORTER, Strategy, supra note 140, at 133-34 \& 185-86.

247. See supra note 193 and accompanying text. 
channels. ${ }^{248}$ If the level of concentration is already high and the market shares of the dominant firms substantially exceed those of "bad" competitors, the large firms may be able to raise the rivals' costs. ${ }^{249}$

More coinplex strategic injuries may also arise. The facts of the recent case Aspen Ski Co. v. Aspen Highlands Skiing Co. ${ }^{250}$ provide an example. The case involved exclusion of a small rival from a joint marketing program. An earher acquisition allowed the monopohist to exploit on its own the joint marketing program (a multi-day, multi-area lift ticket) in a way that the victim could not duplicate. Experience with the package showed that demand for the multi-area ticket was greater than it was for a single-area ticket. Through merger with a developed area and acquisition of land already licensed for development, the larger firm was able to reap the full benefits of multi-area demand while foreclosing its rival from access to a multi-area offering. ${ }^{251} \mathrm{Had}$ the merger been enjoined, the larger firm's growth would have been internal-the company's existing mountain would have been improved througli the development of the additional terrain that skiers demanded. Introspection would have driven the improvements, and when the quality of choices at one mountam exceeded consumer perceptions of the value of the multiarea ticket, consumer preference for more varied terrain would be reflected in a flattened multi-area demand curve. Had Aspen Ski's rival sought to prevent it from acquiring the exploitative position througl1 merger, its theory of injury would have asserted that the merger of separate units was likely to allow the merged firn to prevent it from participating in a marketing device it had helped to develop.

\section{Noninjurious Mergers}

The earlier discussion of the legislative history of the Clayton Act indicates that Congress did not intend to foreclose a merger of two firns that enables the merged firm to attain scale economies in order to compete with an existing larger firm. ${ }^{252}$ Porter's research suggests that the result in Cargill may actually have been true to that congressional intent. Porter uses the beef industry as an example of a fragmented industry

248. See Davidson, supra note 62 , at $459-60$.

249. Recent research concludes that firms may strategically raise the costs of their competitors. See Krattenmaker \& Salop, Anticompetitive Exclusion: Raising Rivals' Costs to Achieve Power Over Price, 96 YALE L.J. 209 (1986). Professor Hovenkamp paraphrases this lesson, showing that economies of scale can be used strategically. When a firm or group of firms establishes a cost of doing business, like advertising, which is relatively constant between firms, that cost is susceptible to economies of scale and is purely strategic if not imposed by market forces. Hovenkamp, supra note 66 , at $278-79$.

250. 472 U.S. 585 (1985).

251. The Court found that Aspen Ski Company was willing to sacrifice short run benefits and consumer welfare in exchange for perceived long-run losses of its smaller rival. Id. at 610-11.

252. M. PORTER, Strategy, supra note 140 , at 185 . 
movimg naturally toward concentration. Although concentration may not be natural in itself, ${ }^{253}$ technological innovation may spur a restructuring that concentrates an industry. In the beef industry, Porter found that concentration was the result of innovation in feedlot technology. ${ }^{254}$ The lots required considerable capital outlay and produced substantial economies of scale. The industry trend toward concentration was furthered by the integration of lot operators into the processing of feed and beef as well as the distribution of those products. Porter's analysis indicates that a competitor profile of IBP, the dominant firm in the industry, would reveal that it benefits from substantial economies of scale. Demonstrated economies of scale would be a defense to enforcement of the Clayton Act aimed at preventing the merger of smaller firms attempting to duplicate IBP's integration of functions.

Although the price-squeeze alleged in Cargill could plausibly be a forn of parallel strategic behavior by members of one strategic group (integrated beef processors), the record does not distinguish plaintiff Monfort as a member of an interdependent or even independent strategic group. ${ }^{255}$ Furtherinore, the defendants' post-merger beliavior could be characterized as mput bidding and price coinpetition rather than as predatory or disciplinary strategic behavior. The record plaintiffs provided does not support a conclusion that the rivals' costs would be raised artificially-increased demand attributable to the increased capacity of the two largest purchasers of unprocessed beef, the raw material, could bid up the price of that necessary resource.

On the limited strategic record available, Cargill demonstrates that strategic behavior analysis can reveal those mergers toward economies of scale that Congress intended to permit in drafting section 7 of the Clayton Act.

\section{CONCLUSION}

I have attempted to use strategic behavior analysis to illustrate that mergers can facilitate conduct contrary to the purposes of the Clayton Act. Strategic mergers can allow finns to position themselves to define and limit the choices available to their rivals. Such behavior is contrary to the congressional model in which dynamic market forces direct industry evolution. By advancing a plausible theory demonstrating a reasonable probability that disciplinary strategic conduct will follow a merger of rivals, a competitor can show antitrust injury and should be pernitted to establisl1 standing to enjoin the merger. Once standing is established,

253. Id. at 201.

254. See supra notes 88-100 and accompanying text.

255. See Monfort of Colorado, Inc. v. Cargill, Inc., 591 F. Supp. 683, $691-92$ (D. Colo. 1983), aff'd, 761 F.2d 570 (10th Cir. 1985), rev'd, 107 S. Ct. 484 (1986). 
however, the competitor should then carry the burden of proving the merger illegal under established standards of merger law, appealing to statistical presumptions and supplementing statistical evidence with additional strategic behavior analysis.

Jonathan L. Diesenhaus*

* B.A. 1985, University of Colorado, Boulder; third-year student, Boalt Hall School of Law, University of California, Berkeley. 
